\title{
Rainfall and throughfall chemistry in the Atlantic Forest: a comparison between urban and natural areas (São Paulo State, Brazil)
}

\author{
M. Cristina Forti ${ }^{1}$, Denise C. Bicudo ${ }^{2}$, Christine Bourotte ${ }^{3}$, Valdir de Cicco $^{4}$ and \\ Francisco C. S. Arcova ${ }^{4}$
}

${ }^{1}$ Instituto Nacional de Pesquisas Espaciais INPE, CP515 S.J.dos Campos, SP/Brasil CEP 12201-970

${ }^{2}$ Instituto de Botânica, Av. Miguel Stéfano, 3687, CP 4005 São Paulo SP/Brasil CEP 01061-970

${ }^{3}$ NUPEGEL/USP Av Pádua Dias, 11; CP 9, Piracicaba SP/Brasil CEP 13418-900

${ }^{4}$ Instituto Florestal, R. do Horto, 931 São Paulo SP/Brasil CEP 02377-000

Email for corresponding author: forti@cptec.inpe.br

\begin{abstract}
Two areas in the Atlantic Forest (São Paulo State, Brazil), with contrasting environments in respect of human occupation, were monitored from 1999 to 2001 . One area named PEFI $\left(23^{\circ} 38^{\prime} 08^{\prime \prime}-23^{\circ} 40^{\prime} 18^{\prime \prime} \mathrm{S}\right.$ and $\left.46^{\circ} 36^{\prime} 48^{\prime \prime}-46^{\circ} 38^{\prime} 00^{\prime \prime} \mathrm{W}\right)$ at an altitude of $798 \mathrm{~m}$ a.s.1., 526.4 ha in area and about $50 \mathrm{~km}$ from the sea, lies in a State Park within the largest metropolis of South America - São Paulo. The other area, named CUNHA (between $23^{\circ} 13^{\prime} 18^{\prime \prime}$ and $23^{\circ} 16^{\prime} 10^{\prime \prime} \mathrm{S}$ and $45^{\circ} 02^{\prime} 53^{\prime \prime}$ and $45^{\circ} 05^{\prime} 15^{\prime \prime} \mathrm{W}$ ) about $1050 \mathrm{~m}$ a.s.1. with an area of 2854 ha and about 15 $\mathrm{km}$ from the sea, is also within a State Park in the Atlantic Forest, but is surrounded by rural areas and small villages. For each area, the rainfall and throughfall chemistry were examined and $\mathrm{pH}$ and $\mathrm{Na}^{+}, \mathrm{K}^{+}, \mathrm{Mg}^{2+}, \mathrm{Ca}^{2+}, \mathrm{NH}_{4}^{+}, \mathrm{Cl}^{-}, \mathrm{NO}_{3}^{-}$and $\mathrm{SO}_{4}{ }^{2-}$ as well as trace metals were determined. Compared with PEFI, CUNHA is characterised by low chemical fluxes and the largest differences are for the ions such as $\mathrm{Ca}^{2+}$, $\mathrm{H}^{+}, \mathrm{NO}_{3}{ }^{-}$and $\mathrm{SO}_{4}{ }^{2-}$ which are mainly anthropogenic in origin. Differences in throughfall chemical fluxes are linked to the nutritional status of the trees.
\end{abstract}

Keywords: Atlantic Forest, hydrochemistry, nutrient cycles, rainfall, throughfall, water chemistry

\section{Introduction}

In the past, the Atlantic Forest comprised $15 \%$ of Brazilian territory, covering as it did almost the whole of the Brazilian coastal region from $25^{\circ} \mathrm{S}$ (State of Santa Catarina) to $5^{\circ} \mathrm{S}$ (State of Rio Grande do Norte). Since the European colonisation of Brazil in the 16th century, the Atlantic forest has been exploited so that, nowadays, much of its original area is occupied by farms as well as urban and industrial centres, including the major urban centres of South America such as the Metropolitan Region of São Paulo city (State of São Paulo) which is the fourth largest urban centre in the world with 17 million inhabitants. At present, only about $15 \%$ of the original Atlantic Forest in the State of São Paulo is preserved as the Biosphere Reserve. Although protected legally, these areas are still under anthropogenic stress from the presence, nearby, of urban and industrial centres as well as from exposure to the deposition of pollutants transported through long distances from such centres.

This paper presents the results of a hydrogeochemical study of two key locations within the Atlantic Forest, mainly to characterise the evolution of the water chemistry of the rainfall and throughfall over time and to examine regional differences in the solute depositions from the atmosphere to the soil and vegetative canopy. The study was undertaken in the State of São Paulo, Brazil, at sites with contrasting pollution climates; the one is polluted, while the other is nearly pristine. The changes occurring are linked to the nutritional status of the vegetation; temporal and spatial differences in the concentrations of solute transferred from the atmosphere to the vegetation cover and thence to the soil surface are examined. Here, a hypothesis is tested: forested areas constantly exposed to pollutants are prone to 
degradation of their vegetation. A major environmental issue for Brazil is protection of the functioning of the ecosystem as well as of the biological resource of the Atlantic Forest.

\section{Study areas}

The urban forest studied is in the 'Parque Estadual das Fontes do Ipiranga' (PEFI) between parallels $23^{\circ} 38^{\prime} 08^{\prime}$ " and $23^{\circ} 40^{\prime} 18^{\prime \prime} \mathrm{S}$ and meridians $46^{\circ} 36^{\prime} 48^{\prime \prime}$ and $46^{\circ} 38^{\prime} 00^{\prime \prime} \mathrm{W}$ at a mean altitude above sea level of $798 \mathrm{~m}$ (Fernandes et al., 2002) and $50 \mathrm{~km}$ from the sea shore. The PEFI is a biological reserve 526.4 ha in area within the metropolitan region of São Paulo city in the south-eastern region of São Paulo City County. PEFI includes an area of water source preservation and is a reserve of biodiversity, a natural laboratory for basic and applied research, a controlling factor for micro-climate, a protection for the water table, a natural laboratory for educational programmes and an important recreation area for the community (Bicudo et al., 2002). Its climate is

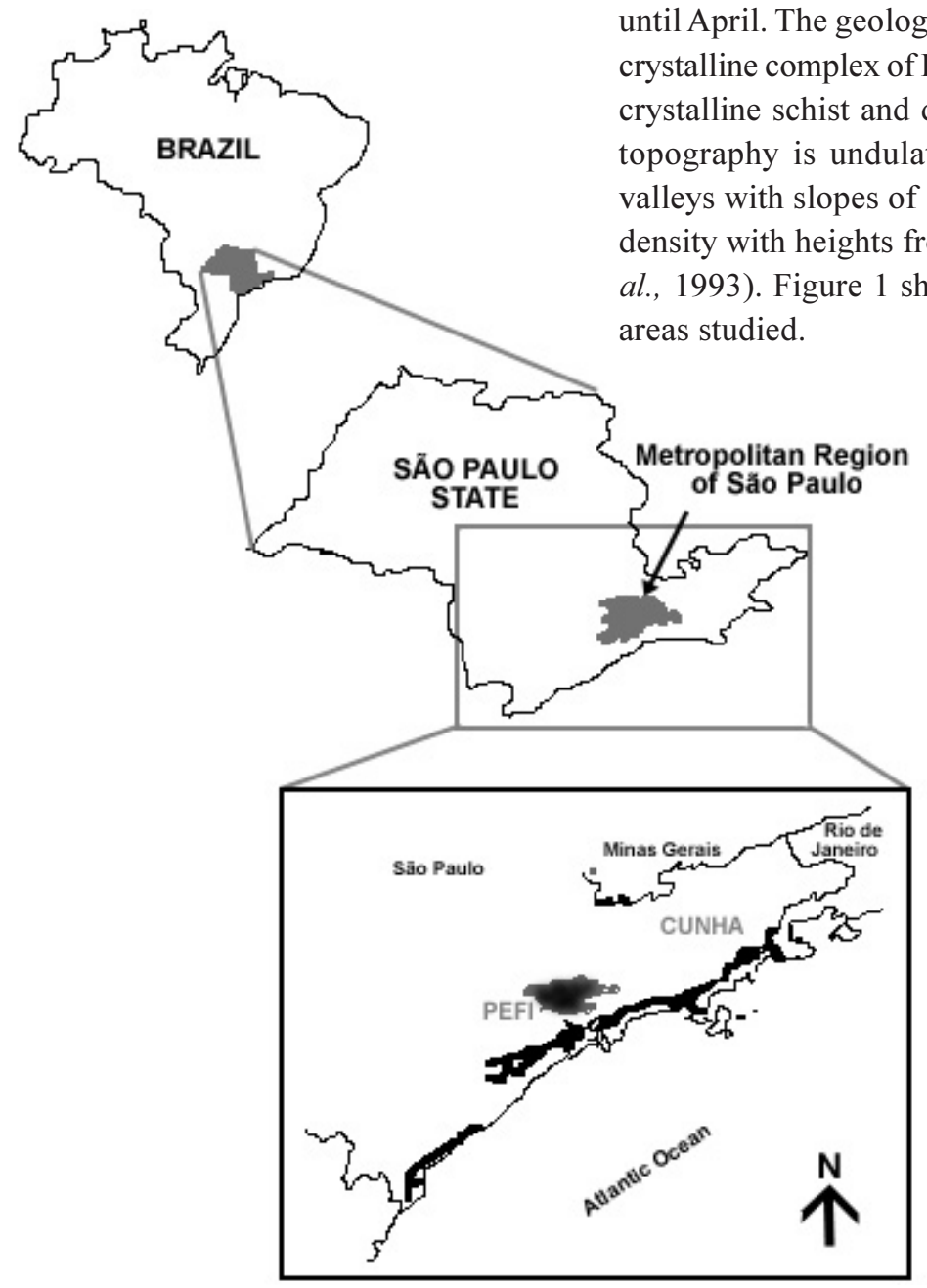

influenced by extra-tropical (e.g. frontal systems) and tropical (e.g. squall lines and convergence zones) systems. The mean annual rainfall (1933-1999) is $1368 \mathrm{~mm}$, with a dry period from May to August. The mean temperature for the coldest month, July, is $15^{\circ} \mathrm{C}$ and for January and February, the two hottest months, $21-22^{\circ} \mathrm{C}$ (Santos and Funari, 2002). It is on crystalline rocks with gneisses and secondary micaschists, overlain by clay, sand and gravels of the São Paulo Formation. The topography is undulating, with heights of $770 \mathrm{~m}$ to $825 \mathrm{~m}$, being part of the central ridge hills of São Paulo city (Almeida, 1974).

The 'CUNHA' is at $1050 \mathrm{~m}$ a.s.1., $15 \mathrm{~km}$ from the sea between $23^{\circ} 13^{\prime} 28^{\prime \prime}$ and $23^{\circ} 16^{\prime} 10^{\prime \prime} \mathrm{S}$ and $45^{\circ} 02^{\prime} 53^{\prime \prime}$ and $45^{\circ} 05^{\prime} 15^{\prime \prime} \mathrm{W}$ with an area of 2854 ha.

It hosts the Walter Emmerich Forest Hydrology Laboratory of the Institute of Forestry of the State of São Paulo. The mean maximum and minimum temperatures are $26^{\circ} \mathrm{C}$ and $16^{\circ} \mathrm{C}$, respectively. The region can be classed as 'mist-tropical' and mean annual rainfall is $1982 \mathrm{~mm}$ (1982-2000) with the main rainy period from September until April. The geology of the area belongs to the Brazilian crystalline complex of Pre-Cambrian with granites, gneisses, diabase rocks of Mesozoic age. The to al., 1993). Figure 1 shows the relative position of the two areas studied.

Fig. 1. Schematic map showing the relative positions of the São Paulo city metropolitan region, PEFI, and CUNHA. 


\section{Methods}

\section{SAMPLING PROCEDURE}

Rainfall and throughfall water for two wet and two dry periods were sampled from June 1999 to December 2001 in the area of the urban forest (PEFI) (70 samples) and from April 2000 to March 2002 in the control forest (CUNHA) (75 samples). Here, the dry and wet periods refer to the driest (May to August) and the wettest (November to February) months. The water samples were accumulated weekly but, if there was insufficient water after 15 days' exposure, the collecting funnel and bottles were substituted with clean ones to minimise dry deposition. The rainfall bulk collector is a polyethylene funnel $167.4 \mathrm{~cm}^{2}$ in collecting area, covered with a nylon mesh of $5 \mathrm{~mm}$ to avoid contamination by insects, branches and leaves, coupled to a 5-L polyethylene bottle. A wet-only collector (MTX-Italy) was deployed simultaneously and the two sets of measurements were used to estimate the effect of dry deposition on the rainfall chemistry.

Throughfall was sampled with ten bulk collectors in a $6 \times$ 6 matrix of 36 sampling points $5 \mathrm{~m}$ apart in a $30 \times 30 \mathrm{~m}$ plot. Each of the 36 points was chosen to avoid trees and understorey vegetation and a $1.5 \mathrm{~m}$ stake was deployed and identified with a number from 1 to 36 . The top of each of the 36 stakes enabled a bulk collector to be installed or removed easily. For each sampling interval, the collectors were sited at ten different positions determined by generation of ten random numbers between 1 and 36. The volume of catch was determined gravimetrically. The ten bulk throughfall samples were mixed in proportion to the sample volumes into one composite sample for chemical analysis (Forti et al., 1997; 2000a).

\section{ANALYTICAL PROCEDURE}

The waters were vacuum filtered with pre-washed membrane Millipore filters of $0.22 \mu \mathrm{m}$ pore diameter to allow the determination of the dissolved fraction and to eliminate micro-organisms and fungi spores that might contaminate and degrade the sample. Three sub-samples were taken for chemical analysis: one stored in a high density polyethylene bottle without preservation for anion analysis, one acidified with supra-pure Nitric Acid (1\% in volume) for the aluminium and transition metal analysis and one acidified with hydrochloric acid $(0.1 \%$ in volume) for cation analysis. After the appropriate preservation, all samples were stored at $4^{\circ} \mathrm{C}$ to avoid sample degradation.

Liquid Ion Chromatography (DIONEX DX500) was employed for the chemical analysis. For the major cations a CS12 analytical column was used with sulphuric acid as eluent. For the anions, an AS4A analytical column was used. Conductivity detection was used for major cations and anions. For the trace metals (Fe III, CuII, Zn II and Mn II) a UV/Visible detector was used with a CS5A analytical column with post-column derivation with 4-(2-piridilasol) resorcinol and pyridine dicarboxilic acid as eluent, with detection at a wavelength of $530 \mathrm{~nm}$; for aluminium the column was the same and the eluent was sulphuric acid/ ammonium sulphate, with post-column reaction involving pyrocatecol violet and detection at a wavelength of $530 \mathrm{~nm}$. The accuracy was checked against certified reference material samples (TM28 and TM 26.2, trace metal fortified water, National Water Research Institute, Ontario Canada, 1999), standards from the United Kingdom Centre for Ecology and Hydrology Hydrochemistry Laboratory (Robson and Neal, 1997) and CRM 409 No. 629 major compounds in simulated rainwater from the Community Bureau of Reference - BCR (Commission of the European Communities). The precision and accuracy of the analysis of the different chemical species in the samples were, respectively, $3 \%$ and $7 \%$ for $\mathrm{Na}^{+}, 3 \%$ and $9 \%$ for $\mathrm{K}^{+}, 8 \%$ and $11 \%$ for $\mathrm{Mg}^{2+}, 8 \%$ and $9 \%$ for $\mathrm{Ca}^{2+}, 10 \%$ and $11 \%$ for $\mathrm{NH}_{4}^{+}, 3 \%$ and $6 \%$ for $\mathrm{Cl}^{-}, 3.5 \%$ and $10 \%$ for $\mathrm{NO}_{3}^{-}, 8 \%$ and $8 \%$ for $\mathrm{SO}_{4}{ }^{2-}, 5 \%$ and $7 \%$ for $\mathrm{Al}$ III, $11 \%$ and $8 \%$ for $\mathrm{Cu}$ II, $11 \%$ and $15 \%$ for Fe III, $4 \%$ and $7 \%$ for Mn II and $7 \%$ and $11 \%$ for $\mathrm{Zn} \mathrm{II} \mathrm{.}$

\section{PRINCIPAL COMPONENT ANALYSIS (PCA)}

Principal component analysis (PCA) was used to reduce the variables to fewer linear combinations of the original variables (Johnson and Wichern, 1988). Broken-stick eigenvalues were used to define the number of interpretable axes (Jackson, 1993). Before computation, variables were log transformed to approximate more closely the linear relationships assumed in PCA. For data processing and plotting, FITOPAC (Shepherd, 1996) and PC-ORD version 3.0 for Windows (McCune and Mefford, 1999) packages were used.

\section{Results and discussion}

\section{COMPARISON BETWEEN WET-ONLY AND BULK COLLECTORS}

A test of the null hypothesis was applied to the wet-only and bulk rainwater samples, with a probability confidence interval of $95 \%$ and significance level of $5 \%$. The results for CUNHA indicate that, except for $\mathrm{NO}_{3}{ }^{-}$, no differences in the composition of the rainwater for all the chemical species of the two sampling groups were statistically 
significant; this finding is in accord with studies in the Amazonian region (Forti et al., 2000b). Correspondingly, the results for PEFI showed that the weighted mean concentration values for $\mathrm{K}^{+}$and $\mathrm{Cl}^{-}$were significantly higher in the samples collected in the bulk collector: dry deposition over the bulk collector was significant during the collection period but the procedure to minimise dry deposition was inefficient for these ions.

Because of the lack of major differences between wetonly and bulk measurements, the study hereafter has been based on the concentrations determined from the samples collected with the bulk collector because one of the objectives of this work is the quantification of the solutes deposited on each ecosystem. The statistical analysis has concluded that rainwater samples accumulated in bulk collectors do not overestimate the concentrations of the chemical species in natural areas or those exposed to low anthropogenic influences. However, the collectors were not exposed for periods longer than seven days.

\section{RAINFALL CHEMISTRY}

Precipitation was measured monthly at the meteorological stations at each site; for the period of the study, these values and the estimates from volume measurements (rainfall and throughfall) are given in Figs. $2 \mathrm{a}$ and $2 \mathrm{~b}$.

Figures 3 (a, b and c) and 4 (a, b and c) present the mean monthly variations in rainwater chemistry for PEFI and CUNHA, respectively. The highest concentrations occur during periods of low rainfall at both sites. However, at PEFI, the concentrations are significantly higher during the driest months (May to August). For CUNHA, concentrations decrease slightly in the rainiest months (November to February). The concentrations vary over time at PEFI which underlines the importance of pollutant scavenging in the atmosphere.

Mean concentrations are calculated as the volume weighted mean (VWM); in Table 1, values for both forests are presented together with maxima and minima for the

(a)

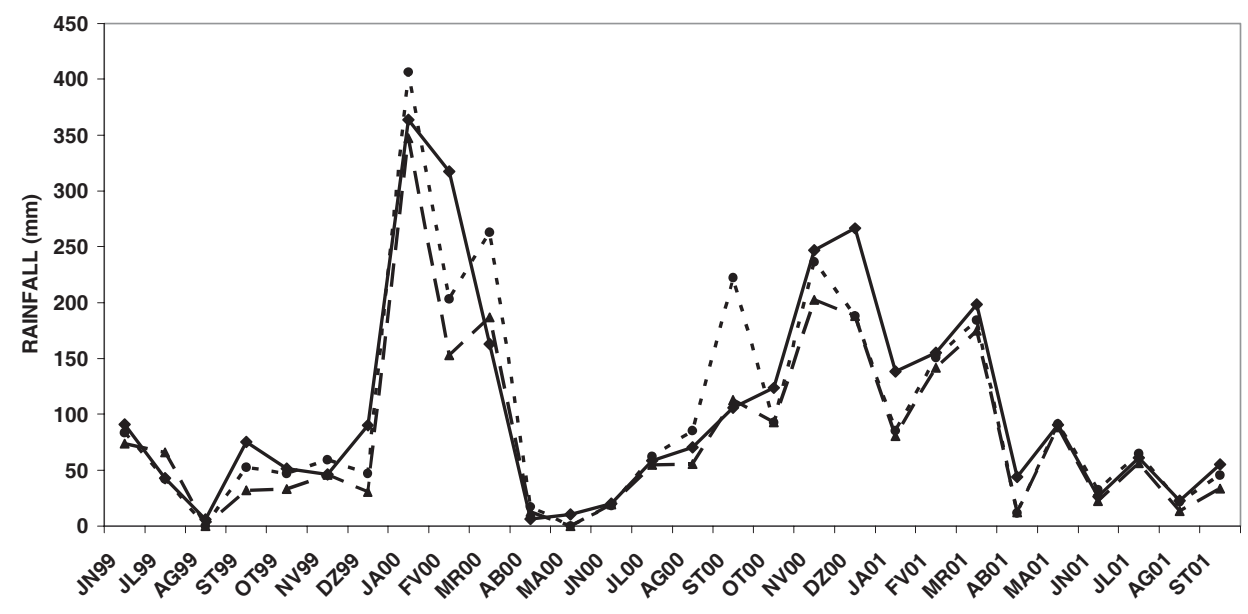

(b)

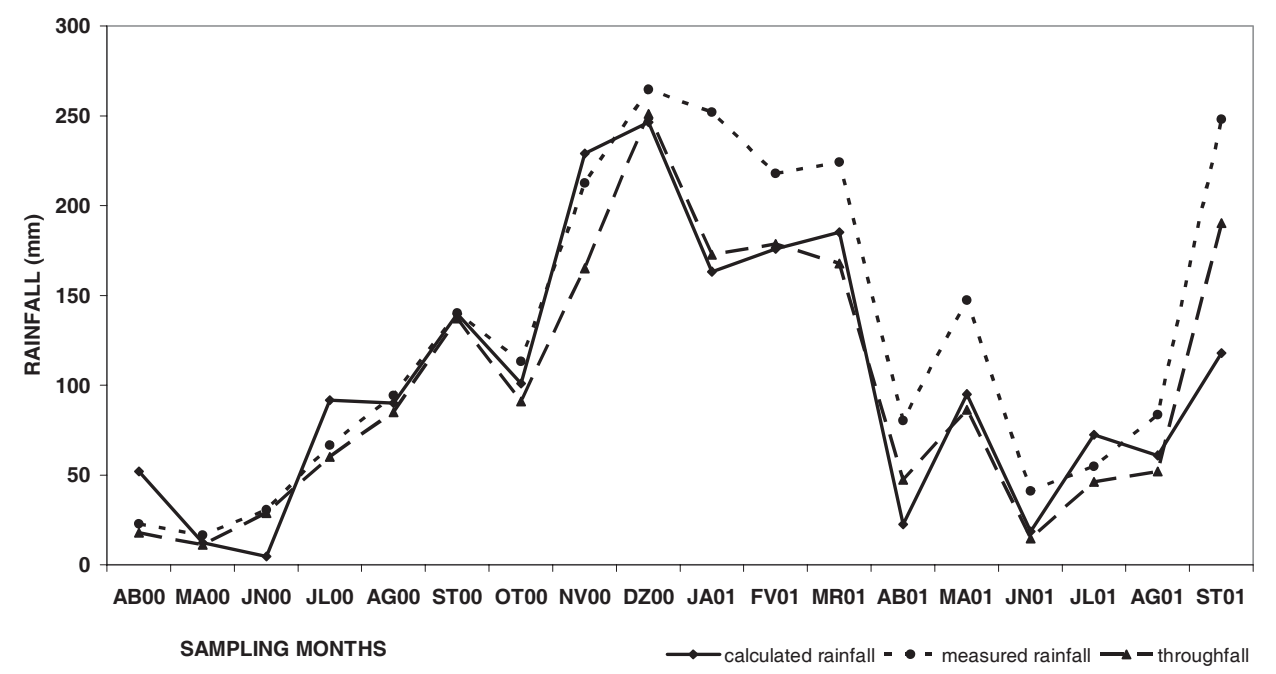

Fig. 2 Monthly mean rainfall in mm at the meteorological station and rainfall and throughfall values calculated from the measured volume for the period studied for (a) the PEFI area and (b) for the CUNHA area 
(a)

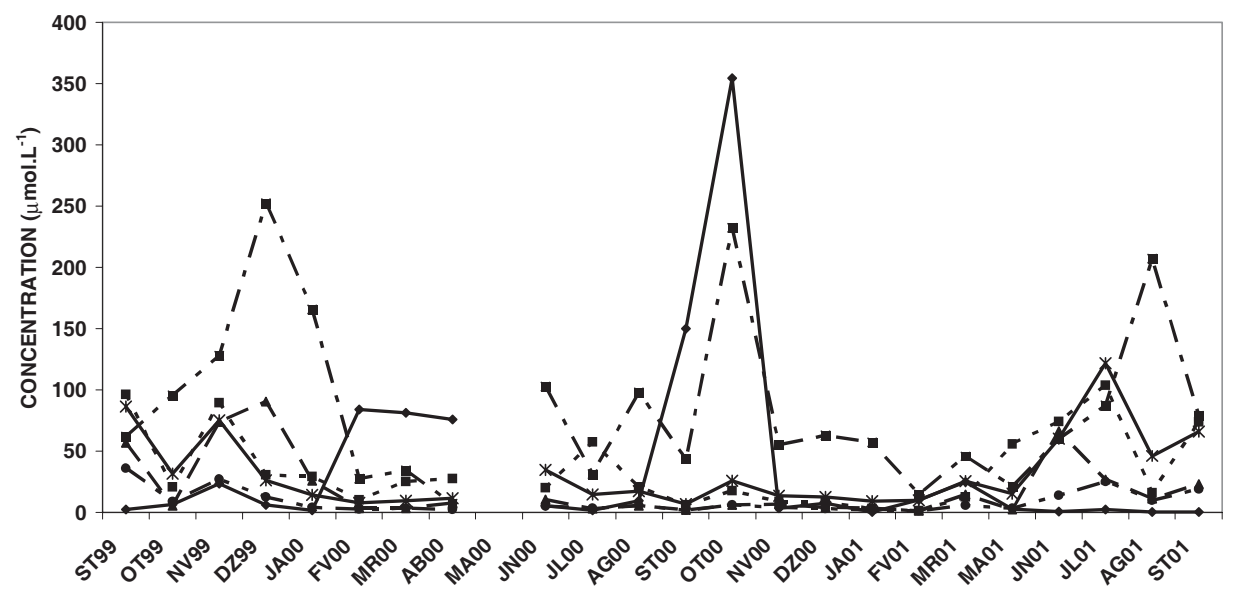

(b)

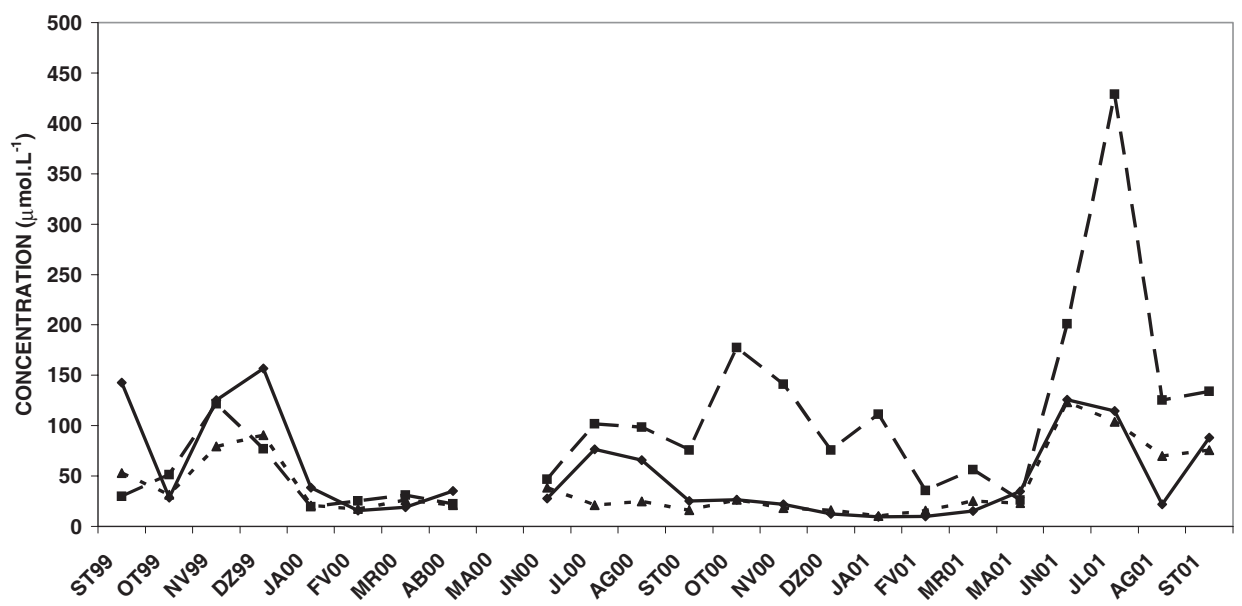

(c)

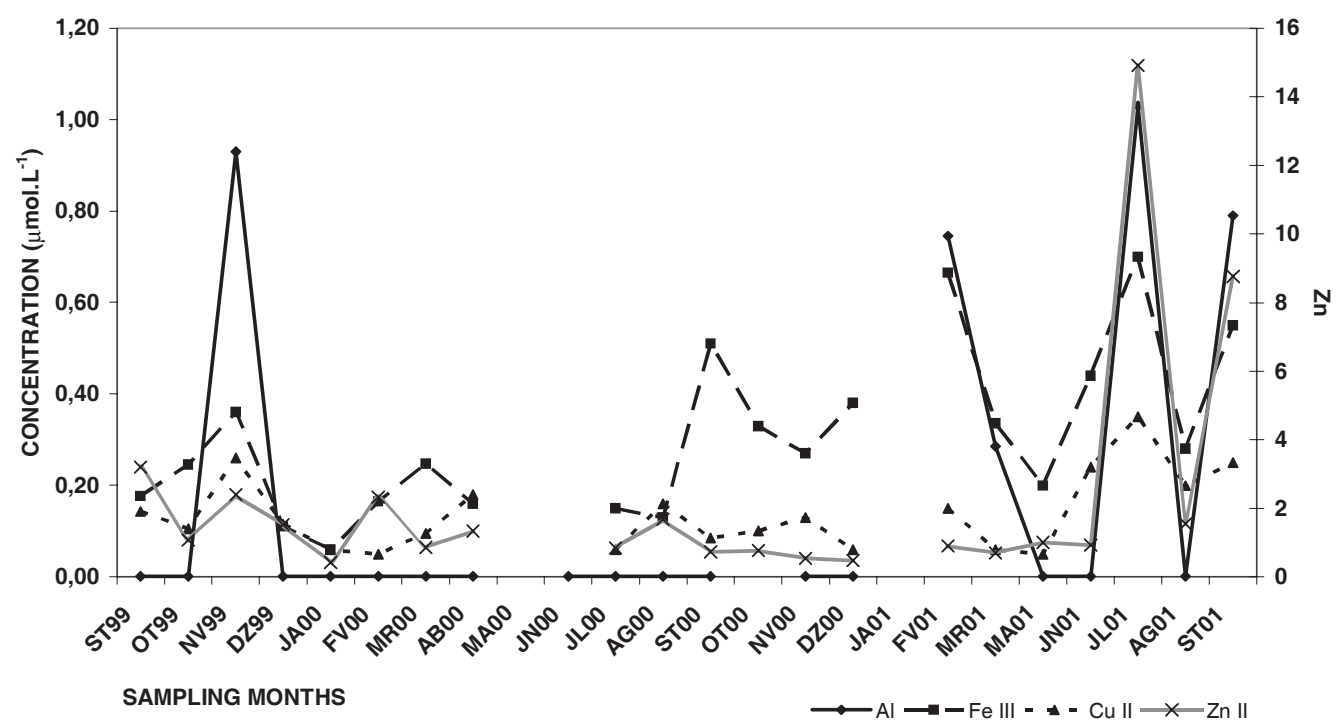

Fig. 3. Rainfall monthly mean concentration variations in different chemicals at PEFI: (a) major cations (b) major anions (c) transition metals.

whole sampling period as well as for the four rainiest and driest months. Clearly, concentrations vary to a large extent.

For PEFI, the rainwater is acidic with a mean $\mathrm{pH}$ of 4.3 and there is no significant statistical difference $(95 \%$ of confidence interval at $5 \%$ of confidence level) between the dry and rainy periods. The mean $\mathrm{pH}$ is about 5.4 for CUNHA, without significant seasonal differences. Trace metal concentrations for rainfall at CUNHA are generally 
Table 1. Rainfall chemistry in $\mu \mathrm{Eq} . \mathrm{L}^{-1}$ for the whole period and the driest and wettest months obtained for PEFI and CUNHA. P: rainfall, mm; N: sample number; MAX: maximum values; MIN: minimum values, MP: volume weighted mean.

\begin{tabular}{|c|c|c|c|c|c|c|c|c|}
\hline & & & Total & $\begin{array}{l}\text { PEFI } \\
\text { Driest }\end{array}$ & Wettest & Total & $\begin{array}{l}\text { CUNHA } \\
\text { Driest }\end{array}$ & Wettest \\
\hline $\mathrm{P}$ & $(\mathrm{mm})$ & & 3143 & 516.7 & 1840 & 3722 & 669.1 & 2006 \\
\hline \multirow[t]{4}{*}{$\mathrm{H}^{+}$} & $\mathrm{N}$ & & 62 & 26 & 36 & 50 & 23 & 27 \\
\hline & MAX & & 368 & 21.5 & 119 & 14.01 & 6.39 & 7.47 \\
\hline & MIN & $\mu \mathrm{Eq} . \mathrm{L}^{-1}$ & 0.01 & 0.01 & 0.45 & 0.13 & 0.52 & 0.36 \\
\hline & MP & & 47.2 & 9.24 & 34.4 & 4.14 & 3.35 & 3.90 \\
\hline \multirow[t]{3}{*}{$\mathrm{Na}^{+}$} & MAX & & 233 & 233 & 33.3 & 41.5 & 41.5 & 14.3 \\
\hline & MIN & $\mu \mathrm{Eq} . \mathrm{L}^{-1}$ & 2.72 & 3.41 & 2.72 & 1.70 & 4.26 & 1.70 \\
\hline & MP & & 15.5 & 31.8 & 11.6 & 8.33 & 12.4 & 5.19 \\
\hline \multirow[t]{3}{*}{$\mathrm{K}^{+}$} & MAX & & 155 & 155 & 52.6 & 31.3 & 7.61 & 22.5 \\
\hline & MIN & $\mu \mathrm{Eq} . \mathrm{L}^{-1}$ & 1.56 & 1.79 & 1.56 & 0.58 & 0.58 & 1.12 \\
\hline & MP & & 11.0 & 12.4 & 12.9 & 8.61 & 2.39 & 9.69 \\
\hline \multirow[t]{3}{*}{$\mathrm{Mg}^{2+}$} & MAX & & 90.2 & 90.2 & 10.2 & 5.47 & 4.11 & 5.47 \\
\hline & MIN & $\mu \mathrm{Eq} . \mathrm{L}^{-1}$ & 1.64 & 2.26 & 1.64 & 0.32 & 0.51 & 0.32 \\
\hline & MP & & 4.38 & 7.09 & 3.40 & 2.29 & 1.08 & 2.53 \\
\hline \multirow[t]{3}{*}{$\mathrm{Ca}^{2+}$} & MAX & & 214 & 214 & 24.4 & 4.24 & 3.69 & 4.24 \\
\hline & MIN & $\mu \mathrm{Eq} . \mathrm{L}^{-1}$ & 5.88 & 9.60 & 5.88 & 0.00 & 0.00 & 0.54 \\
\hline & MP & & 14.7 & 24.6 & 10.7 & 1.89 & 1.22 & 2.01 \\
\hline \multirow[t]{3}{*}{$\mathrm{NH}_{4}^{+}$} & MAX & & 268 & 103 & 161 & 255 & 19.6 & 255 \\
\hline & MIN & $\mu \mathrm{Eq} . \mathrm{L}^{-1}$ & 2.83 & 8.04 & 7.26 & 0.79 & 0.79 & 2.17 \\
\hline & MP & & 59.9 & 39.7 & 57.2 & 38.0 & 8.71 & 57.6 \\
\hline \multirow[t]{3}{*}{$\mathrm{Cl}_{-}$} & MAX & & 345 & 345 & 58.5 & 106 & 35.5 & 11.2 \\
\hline & MIN & $\mu \mathrm{Eq} . \mathrm{L}^{-1}$ & 5.12 & 5.12 & 9.60 & 4.14 & 5.89 & 7.50 \\
\hline & MP & & 27.2 & 52.3 & 22.3 & 14.4 & 10.9 & 5.18 \\
\hline \multirow[t]{3}{*}{$\mathrm{NO}_{3}^{-}$} & MAX & & 427 & 427 & 135 & 33.1 & 22.2 & 12.1 \\
\hline & MIN & $\mu \mathrm{Eq} . \mathrm{L}^{-1}$ & 5.83 & 5.83 & 13.6 & 0.28 & 3.43 & 0.50 \\
\hline & MP & & 65.2 & 113 & 49.0 & 8.00 & 9.69 & 5.53 \\
\hline \multirow[t]{3}{*}{$\mathrm{SO}_{4}^{2-}$} & MAX & & 133 & 133 & 47.2 & 11.5 & 7.64 & 7.63 \\
\hline & MIN & $\mu \mathrm{Eq} . \mathrm{L}^{-1}$ & 6.43 & 13.8 & 6.43 & 1.78 & 1.78 & 2.07 \\
\hline & $\mathrm{MP}$ & & 23.7 & 29.5 & 21.4 & 4.16 & 3.80 & 3.69 \\
\hline \multirow[t]{4}{*}{ Al III } & $\mathrm{N}$ & & 43 & 16 & 27 & 20 & 13 & 7 \\
\hline & MAX & & 1.58 & 1.03 & 0.62 & 10.1 & 1.23 & 10.1 \\
\hline & MIN & $\mu \mathrm{Eq} . \mathrm{L}^{-1}$ & 0.00 & 0.001 & 0.001 & 0.00 & 0.00 & 0.02 \\
\hline & MP & & 0.17 & 0.13 & 0.07 & 2.93 & 1.59 & 3.74 \\
\hline \multirow[t]{3}{*}{ Fe III } & MAX & & 0.87 & 0.70 & 0.47 & 0.31 & 0.05 & 0.31 \\
\hline & MIN & $\mu \mathrm{Eq} . \mathrm{L}^{-1}$ & 0.06 & 0.15 & 0.06 & 0.00 & 0.00 & 0.00 \\
\hline & $\mathrm{MP}$ & & 0.27 & 0.24 & 0.21 & 0.04 & 0.02 & 0.05 \\
\hline \multirow[t]{3}{*}{$\mathrm{Cu}$ II } & MAX & & 0.35 & 0.35 & 0.15 & 0.44 & 0.05 & 0.44 \\
\hline & MIN & $\mu \mathrm{Eq} . \mathrm{L}^{-1}$ & 0.04 & 0.05 & 0.04 & 0.00 & 0.00 & 0.00 \\
\hline & MP & & 0.09 & 0.12 & 0.07 & 0.06 & 0.01 & 0.10 \\
\hline \multirow[t]{3}{*}{ Zn II } & MAX & & 16.0 & 14.9 & 3.30 & 2.06 & 2.01 & 1.20 \\
\hline & MIN & $\mu \mathrm{Eq} . \mathrm{L}^{-1}$ & 0.38 & 0.38 & 0.40 & 0.00 & 0.14 & 0.00 \\
\hline & MP & & 2.18 & 2.72 & 1.00 & 0.24 & 0.36 & 0.23 \\
\hline \multirow[t]{3}{*}{ Mn II } & MAX & & 1.69 & 1.69 & 0.26 & 0.18 & 0.18 & 0.12 \\
\hline & MIN & $\mu \mathrm{mEq} . \mathrm{L}^{-1}$ & 0.07 & 0.07 & 0.07 & 0.00 & 0.00 & 0.00 \\
\hline & MP & & 0.19 & 0.38 & 0.12 & 0.04 & 0.05 & 0.03 \\
\hline
\end{tabular}


(a)

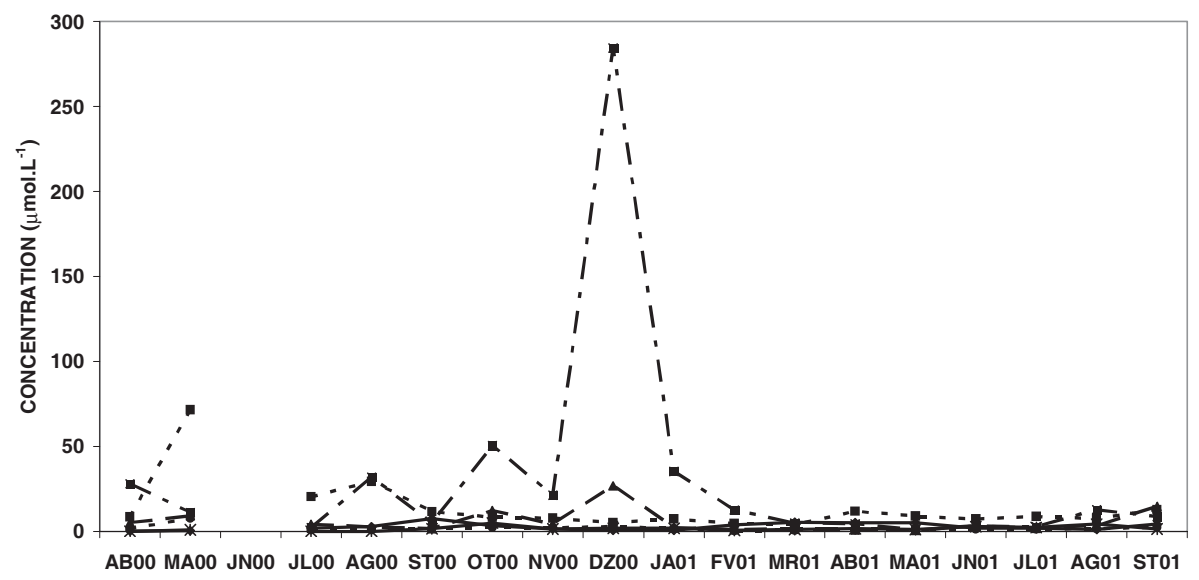

(b)

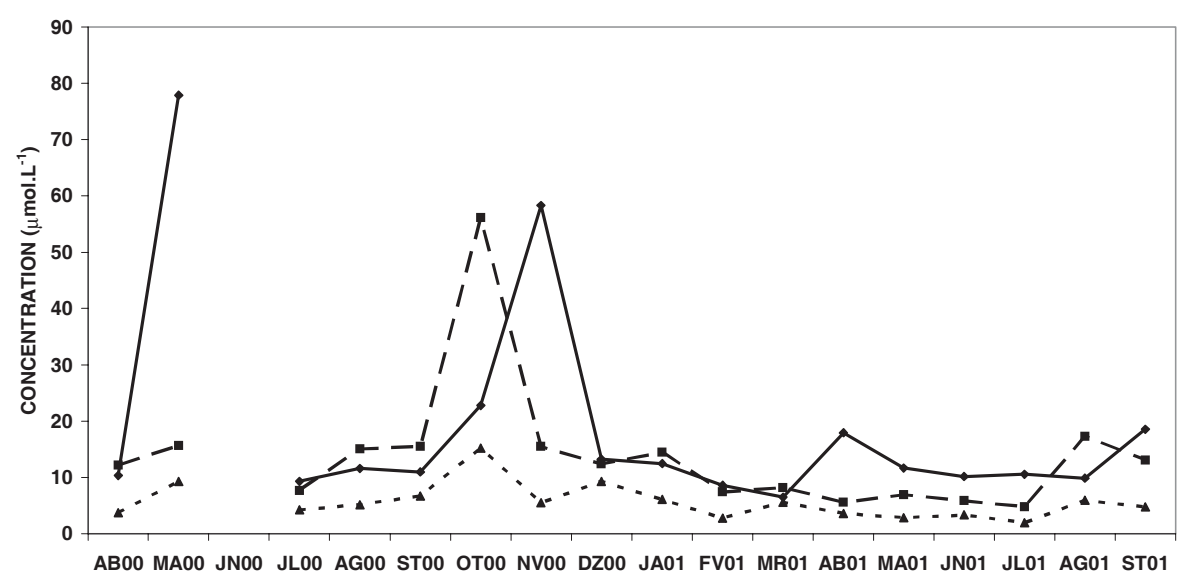

(c)

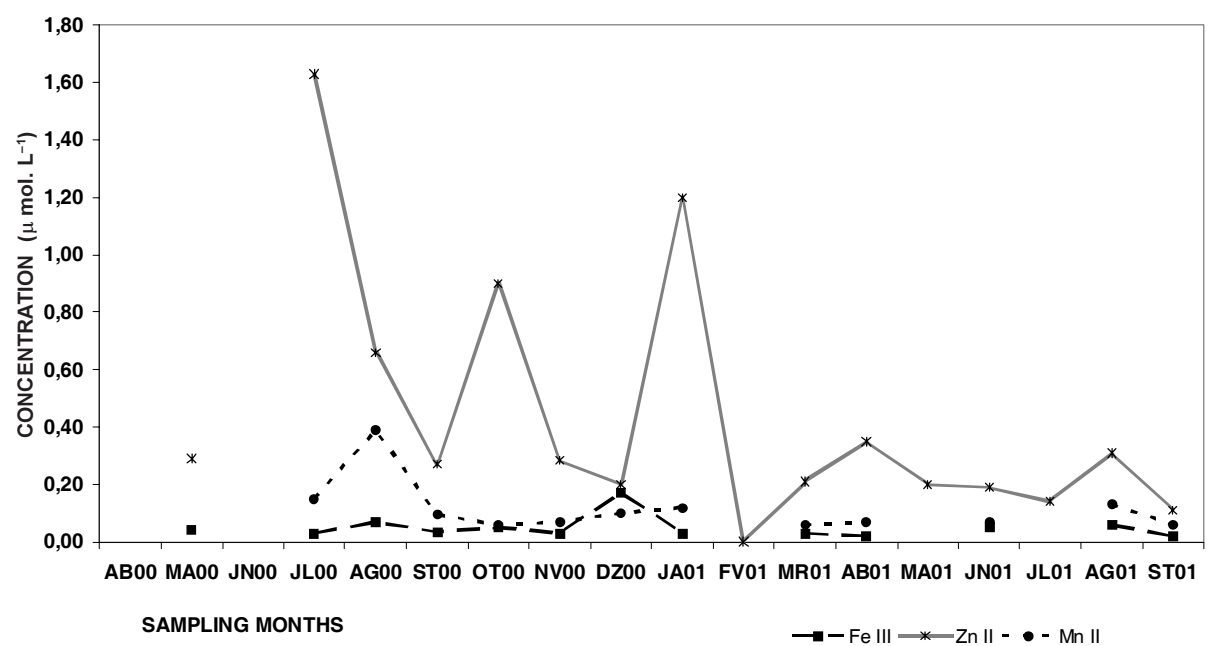

Fig. 4. Rainfall monthly mean concentration variations in different chemicals at CUNHA: (a) major cations (b) major anions (c) transition metals.

close to the detection limits, except for Zn II and Mn II, while for PEFI the concentrations are within the confidence intervals of the analytical method.

Statistical evaluation (to $95 \%$ probability) showed a difference between the wet and dry season for the rainfall but not for the mean values of all the chemical determinands at both sites.

\section{THROUGHFALL CHEMISTRY}

Figures 5 (a, b and c) and 6 (a, b and c) show mean monthly variations (VWM) for each chemical species in throughfall for PEFI and CUNHA, respectively. In both regions, the concentrations for all chemical species are significantly higher in the driest than in the wettest period, because the vegetation is an efficient filter for the airborne particulates 
(a)

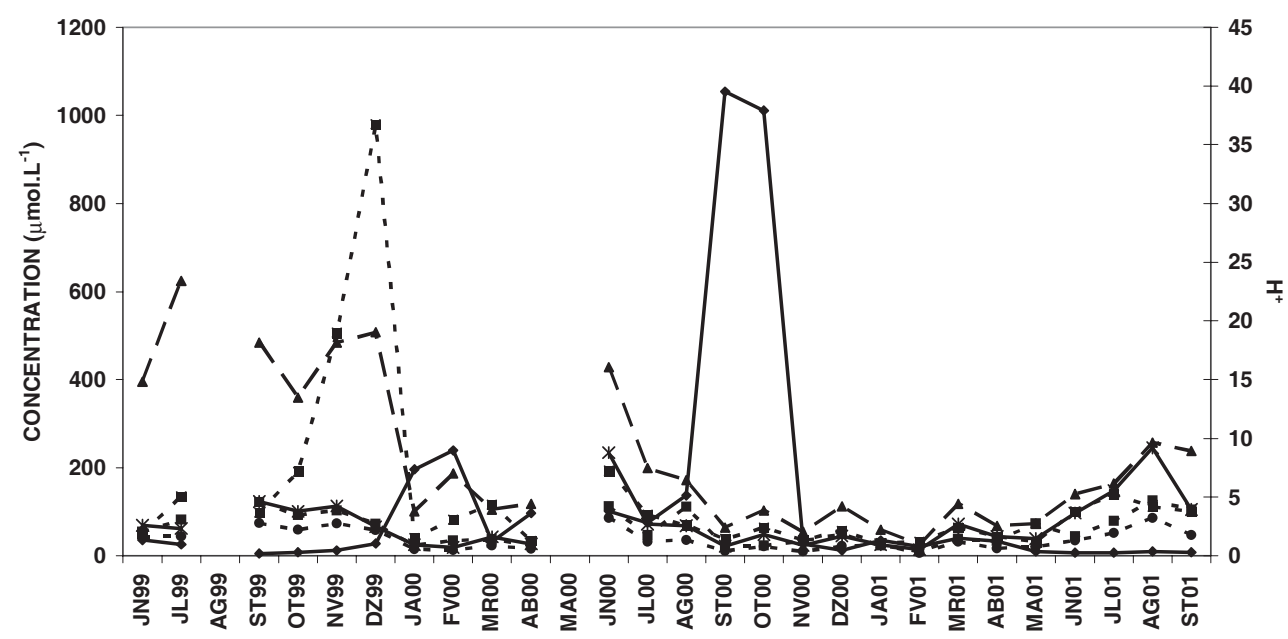

(b)

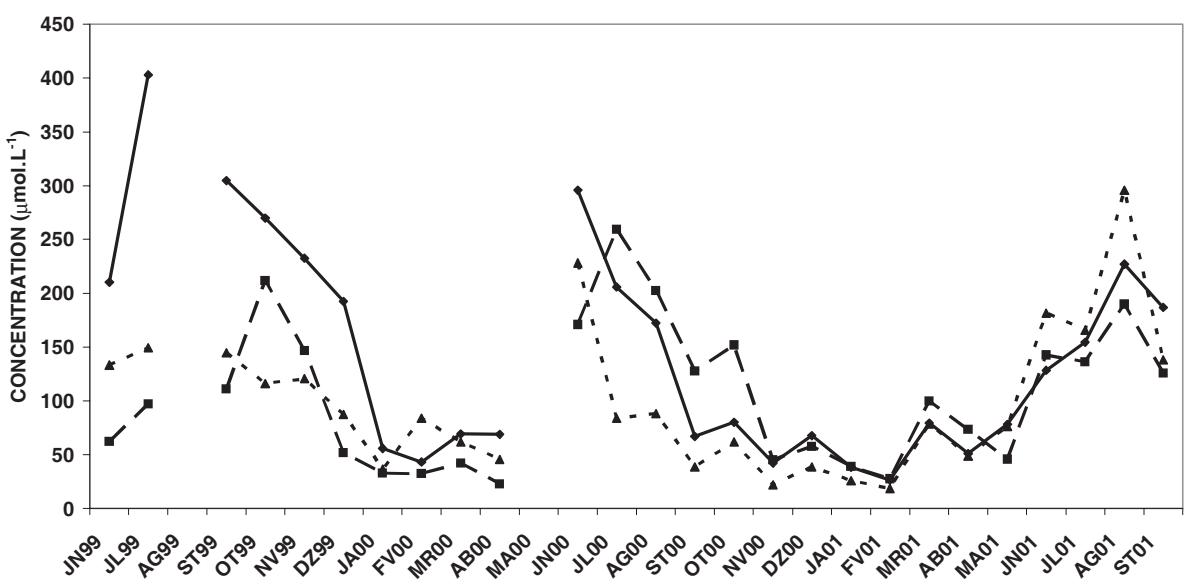

(c)

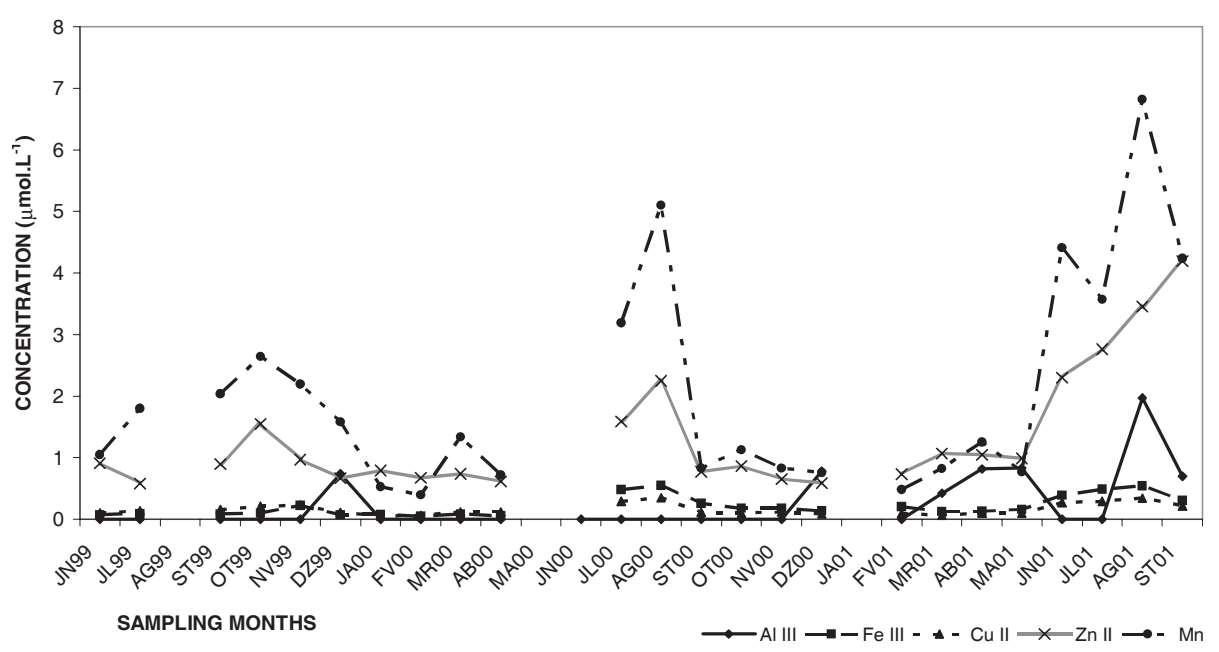

Fig. 5. Throughfall monthly mean concentration variations in different chemicals at PEFI: (a) major cations (b) major anions (c) transition metals.

that become trapped in the canopies. The foliage is an active scavenger for several atmospheric components; when rain falls, it interacts with the components in the canopy to form throughfall solutions which interact with the vegetation. Several processes are involved such as wash of soluble species like $\mathrm{Na}^{+}$and $\mathrm{Cl}^{-}$deposited over the vegetation, leaching of soluble species present like $\mathrm{K}^{+}$in the foliar tissue or like $\mathrm{Ca}^{2+}$ in its structure, the absorption of available nutrients such as $\mathrm{NH}_{4}^{+}$and $\mathrm{NO}_{3}{ }^{-}$or precipitated like Al III due to $\mathrm{pH}$ changes. Even trace metals, essential elements for biological processing, can be leached. In polluted areas such as PEFI, where the anthropogenic inputs are very high, 
(a)

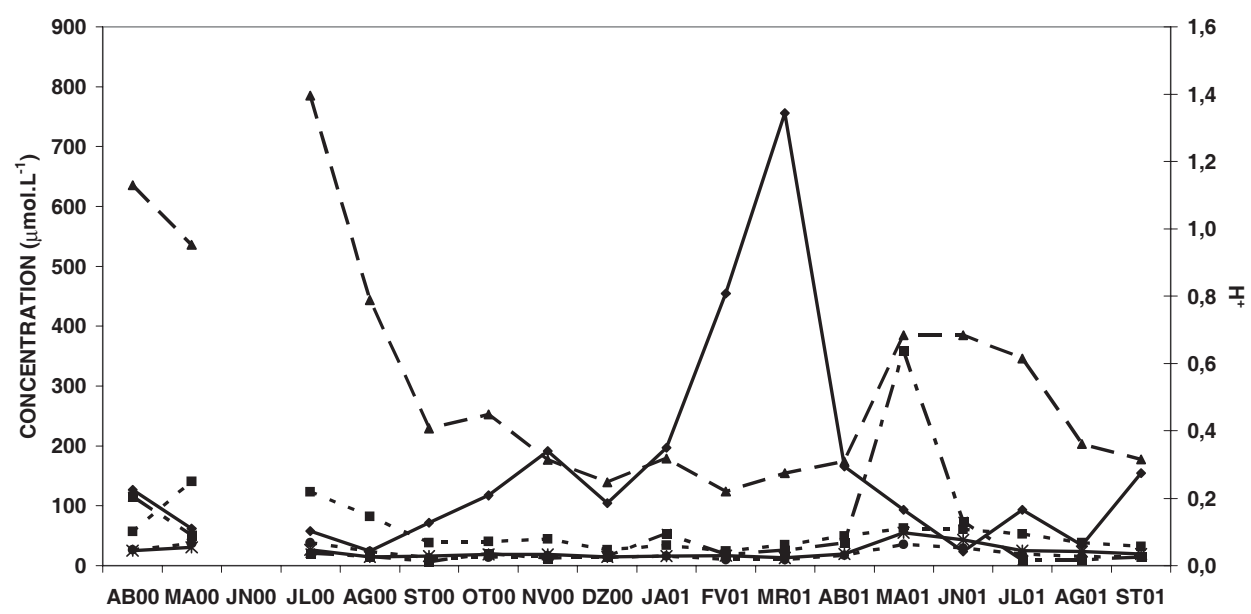

(b)

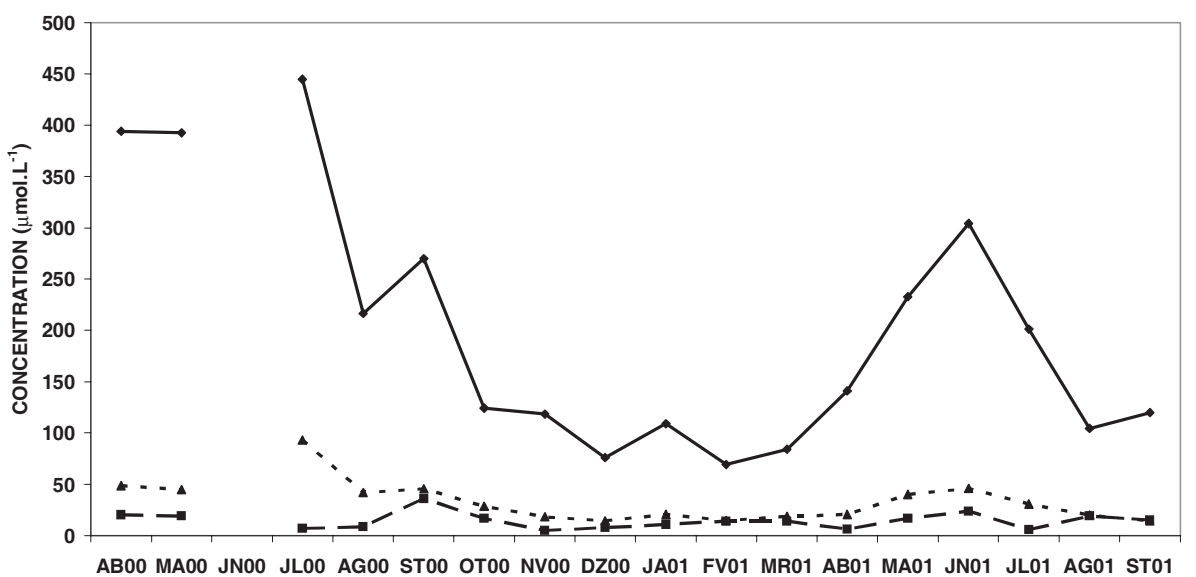

(c)

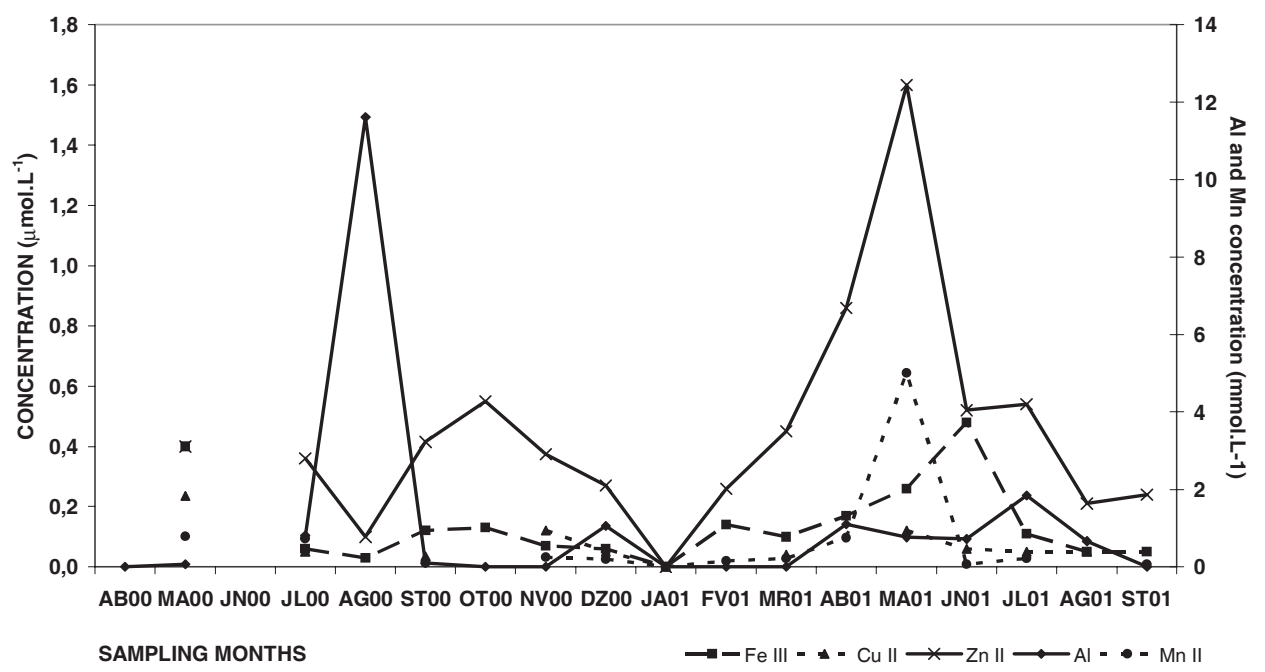

Fig. 6. Throughfall monthly mean concentration variations in different chemicals at CUNHA: (a) major cations (b) major anions (c) transition metals.

the natural processes of throughfall formation are altered due to the excess of chemicals present in the rainfall and deposited on the vegetation.

Table 2 presents the throughfall chemistry for the whole period and for the four driest and wettest months at both PEFI and CUNHA. The mean throughfall $\mathrm{pH}$ is higher at
CUNHA (6.4) than at PEFI (5.3) and, although at CUNHA a seasonal difference is significant statistically, it is not so at PEFI. The PEFI's throughfall is slightly acid indicating that the bases leached from the vegetation and solubilised from the dry deposited material are insufficient to neutralise the acidity introduced by the rainfall. A hypothesis test of 
Table 2. Throughfall chemistry in $\mu \mathrm{Eq} . \mathrm{L}^{-1}$ for the whole (TOTAL) period and the driest and wettest months obtained for PEFI and CUNHA. PTR: throughfall amount mm; N: sample number; MAX: maximum values; MIN: minimum values, MP: volume weighted mean.

\begin{tabular}{|c|c|c|c|c|c|c|c|}
\hline & & & PEFI & & & UNHA & \\
\hline & & Total & Driest & Wettest & Total & Driest & Wettest \\
\hline PTR & $(\mathrm{mm})$ & 2726 & 488.2 & 1445 & 2975 & 498.8 & 1672 \\
\hline $\mathrm{H}^{+}$ & $\mathrm{N}$ & 62 & 26 & 36 & 50 & 23 & 27 \\
\hline & $\operatorname{MAX} \mu \mathrm{Eq} \cdot \mathrm{L}^{-1}$ & 62.1 & 6.23 & 12.5 & 1.36 & 0.20 & 0.75 \\
\hline & MIN & 0.10 & 0.10 & 0.40 & 0.04 & 0.04 & 0.13 \\
\hline & MP & 5.45 & 1.96 & 4.08 & 0.39 & 0.12 & 0.41 \\
\hline $\mathrm{Na}^{+}$ & MAX $\mu \mathrm{mEq} \cdot \mathrm{L}^{-1}$ & 135 & 135 & 48.6 & 129 & 129 & 32.0 \\
\hline & $\mathrm{MIN}$ & 11.0 & 41.1 & 15.8 & 19.9 & 32.7 & 19.9 \\
\hline & MP & 35.2 & 64.6 & 28.6 & 36.4 & 62.1 & 27.3 \\
\hline $\mathrm{K}^{+}$ & $\operatorname{MAX} \mu \mathrm{Eq} \cdot \mathrm{L}^{-1}$ & 518 & 518 & 334 & 782 & 782 & 218 \\
\hline & MIN & 11.8 & 84.8 & 45.5 & 98.9 & 167 & 99.0 \\
\hline & MP & 125 & 224 & 107 & 189 & 361 & 128 \\
\hline $\mathrm{Mg}^{2+}$ & $\operatorname{MAX} \mu \mathrm{Eq} \cdot \mathrm{L}^{-1}$ & 114 & 114 & 40.3 & 43.4 & 43.4 & 29.6 \\
\hline & MIN & 9.57 & 17.8 & 9.57 & 9.41 & 10.4 & 9.41 \\
\hline & MP & 20.9 & 37.6 & 15.7 & 16.2 & 20.3 & 14.1 \\
\hline $\mathrm{Ca}^{2+}$ & $\operatorname{MAX} \mu \mathrm{Eq} \cdot \mathrm{L}^{-1}$ & 245 & 245 & 55.3 & 46.2 & 40.4 & 18.8 \\
\hline & MIN & 15.2 & 32.6 & 15.2 & 9.02 & 9.02 & 9.90 \\
\hline & MP & 30.1 & 78.8 & 23.8 & 17.8 & 20.3 & 14.4 \\
\hline $\mathrm{NH}_{4}^{+}$ & $\operatorname{MAX} \mu \mathrm{Eq} \cdot \mathrm{L}^{-1}$ & 467 & 193 & 379 & 115 & 76.4 & 38.4 \\
\hline & $\mathrm{MIN}$ & 0.97 & 38.4 & 0.97 & 8.01 & 8.01 & 8.67 \\
\hline & MP & 68.0 & 66.6 & 63.0 & 24.5 & 27.1 & 22.6 \\
\hline $\mathrm{Cl}-$ & $\operatorname{MAX} \mu \mathrm{Eq} \cdot \mathrm{L}^{-1}$ & 366 & 366 & 163 & 442 & 442 & 135 \\
\hline & $\mathrm{MIN}$ & 25.8 & 61.5 & 34.9 & 53.7 & 98.3 & 53.7 \\
\hline & MP & 74.2 & 165 & 48.7 & 116 & 228 & 76.0 \\
\hline $\mathrm{NO}_{3}^{-}$ & $\operatorname{MAX} \mu \mathrm{Eq} \cdot \mathrm{L}^{-1}$ & 269 & 269 & 78.1 & 39.7 & 39.7 & 15.3 \\
\hline & MIN & 22.5 & 56.2 & 25.7 & 2.30 & 6.14 & 2.30 \\
\hline & $\mathrm{MP}$ & 65.5 & 121 & 39.3 & 9.85 & 20.0 & 6.23 \\
\hline $\mathrm{SO}_{4}^{2-}$ & $\operatorname{MAX} \mu \mathrm{Eq} \cdot \mathrm{L}^{-1}$ & 296 & 296 & 84.7 & 114 & 114 & 22.9 \\
\hline & MIN & 21.7 & 45.3 & 21.7 & 7.06 & 16.6 & 7.06 \\
\hline & MP & 55.5 & 104 & 40.6 & 21.0 & 46.0 & 13.4 \\
\hline Al III & $\mathrm{N}$ & 43 & 16 & 27 & 20 & 13 & 7 \\
\hline & $\operatorname{MAX} \mu \mathrm{Eq} \cdot \mathrm{L}^{-1}$ & 1.97 & 1.97 & 0.78 & 10.1 & 10.1 & 1.23 \\
\hline & MIN & 0.01 & 0.01 & 0.01 & 0.00 & 0.02 & 0.00 \\
\hline & MP & 0.18 & 0.21 & 0.12 & 0.51 & 2.20 & 0.22 \\
\hline Fe III & $\operatorname{MAX} \mu \mathrm{Eq} \cdot \mathrm{L}^{-1}$ & 0.54 & 0.54 & 0.22 & 0.48 & 0.48 & 0.36 \\
\hline & $\mathrm{MIN}$ & 0.01 & 0.01 & 0.05 & 0.00 & 0.05 & 0.00 \\
\hline & MP & 0.14 & 0.25 & 0.10 & 0.07 & 0.13 & 0.06 \\
\hline $\mathrm{Cu}$ II & $\operatorname{MAX} \mu \mathrm{Eq} \cdot \mathrm{L}^{-1}$ & 0.34 & 0.34 & 0.18 & 0.25 & 0.25 & 0.20 \\
\hline & $\mathrm{MIN}$ & 0.01 & 0.01 & 0.04 & 0.00 & 0.03 & 0.00 \\
\hline & $\mathrm{MP}$ & 0.10 & 0.18 & 0.07 & 0.04 & 0.07 & 0.03 \\
\hline Zn II & MAX $\mu \mathrm{Eq} \cdot \mathrm{L}^{-1}$ & 4.19 & 3.45 & 0.98 & 1.60 & 1.60 & 0.34 \\
\hline & MIN & 0.01 & 0.01 & 0.48 & 0.00 & 0.21 & 0.00 \\
\hline & MP & 0.93 & 1.35 & 0.56 & 0.28 & 0.62 & 0.15 \\
\hline Mn II & $\operatorname{MAX} \mu \mathrm{Eq} \cdot \mathrm{L}^{-1}$ & 6.82 & 6.82 & 1.86 & 5.00 & 5.00 & 0.21 \\
\hline & MIN & 0.01 & 0.01 & 0.29 & 0.00 & 0.00 & 0.00 \\
\hline & $\mathrm{MP}$ & 1.12 & 2.20 & 0.55 & 0.28 & 1.15 & 0.08 \\
\hline
\end{tabular}


the difference between the mean values for throughfall for the wet and dry periods was undertaken for all chemicals at both sites. There was no statistically significant difference for $\mathrm{H}^{+}, \mathrm{K}^{+}, \mathrm{NH}_{4}^{+}$and $\mathrm{Al}$ III for PEFI and for $\mathrm{Mg}^{2+}, \mathrm{NH}_{4}^{+}$ and $\mathrm{NO}_{3}^{-}$for CUNHA. The other ions showed significant differences between wet and dry periods.

PCA analyses were carried out for PEFI and CUNHA rainfall and throughfall variables separately. According to the broken-stick model, PCA extracted two interpretable axes of variation from the 13 chemical water variables (Tables 3 and 4) over the entire observational period accordingly with the climatic characteristics: the wettest, driest and transitional months (time interval between the wet and dry seasons).

For PEFI rainfall (Fig. 7a) and throughfall (Fig. 7b), the eigen-values of the two first principal components accounted for $69.2 \%$ and $76.5 \%$ of the total variance of the observations, respectively (Table 3 ). Six (rainfall) and eight (throughfall) variables contributed most to the construction of component $1(\mathrm{r}>0.6)$. This axis was related negatively to major ionic species except for $\mathrm{NH}_{4}^{+}$and $\mathrm{NO}_{3}{ }^{-}$for rainfall (Table 3). On the second axis, transition metals were the main variables indicating the diverse processes involved in the incorporation of transition metals in the rainfall and throughfall. For rainfall chemistry, both axes do not contrast

Table 3. Loadings of variables on the first two principal components for rainfall (R) and throughfall (TR) water samples in PEFI and the proportion of variance explained by each component.

\begin{tabular}{lcccc}
\hline & \multicolumn{2}{c}{ Rainfall } & \multicolumn{2}{c}{ Throughfall } \\
Variable & PC 1-R & PC 2-R & PC 1-TR & PC 2-TR \\
\hline $\mathrm{Na}^{+}$ & -0.78 & 0.40 & -0.83 & 0.25 \\
$\mathrm{~K}^{+}$ & -0.73 & 0.38 & -0.68 & 0.39 \\
$\mathrm{Mg}^{2+}$ & -0.91 & 0.32 & -0.93 & 0.29 \\
$\mathrm{Ca}^{2+}$ & -0.93 & 0.20 & -0.93 & 0.19 \\
$\mathrm{NH}_{4}^{+}$ & 0.08 & 0.31 & -0.58 & 0.50 \\
$\mathrm{Cl}^{-}$ & -0.80 & 0.42 & -0.91 & 0.32 \\
$\mathrm{NO}_{3}^{-}$ & -0.07 & -0.48 & -0.78 & 0.03 \\
$\mathrm{SO}_{4}^{2-}$ & -0.85 & 0.24 & -0.90 & 0.20 \\
$\mathrm{Al} \mathrm{III}_{\mathrm{Fe} \mathrm{III}}$ & -0.29 & -0.84 & -0.18 & -0.42 \\
$\mathrm{Cu}_{\mathrm{II}}$ & -0.18 & -0.80 & -0.42 & -0.80 \\
$\mathrm{Zn}$ II & -0.71 & -0.59 & -0.70 & -0.62 \\
Mn II & -0.63 & -0.63 & -0.49 & -0.81 \\
Observed & -0.58 & -0.61 & -0.72 & -0.63 \\
$\quad$ eigenvalue & 5.56 & 3.43 & 6.94 & 3.04 \\
Broken-Stick & & & & \\
$\quad$ eigenvalue & 3.18 & 2.18 & 3.18 & 2.18 \\
\% of variance & 42.80 & 26.37 & 53.40 & 23.11 \\
\hline
\end{tabular}

samples from the climatic characteristics indicating a lack of seasonal variation in agreement with the tests of the hypothesis. However, for throughfall chemistry, the first axis contrasts samples from the dry months (which were positively associated with major ionic species) with those from the other periods, mainly the wet months.

The eigen-values of the two first principal components for CUNHA, rainfall (Fig. 8a) and throughfall (Fig. 8b) represent, respectively, up to $60.7 \%$ and $60 \%$ of the total variance of the observations (Table 4). For rainfall, five variables contributed most to the construction of component $1(r>0.6)$. This axis was negatively related with the major ionic species except for $\mathrm{Na}^{+}$and $\mathrm{Ca}^{2+}$ (Table 4). On the second axis, two transition metals, (Fe III and $\mathrm{Cu}$ II) and $\mathrm{Na}^{+}$were the main variables. For throughfall, the major ionic species were highly correlated $(r>0.6)$ with the first axis (except for $\mathrm{NO}_{3}^{-}$) and all transition metals to the second component, indicating that the terrigenous source is accountable for a significant part (16\%) of the total variance (Table 4). As was found for PEFI, the analysis indicates no seasonal variation in rainfall chemistry. However, throughfall chemistry was even more clearly separated into wet and dry periods than in PEFI.

Table 4. Loadings of variables on the first two principal components for rainfall (R) and throughfall (TR) water samples in CUNHA and the proportion of variance explained by each component.

\begin{tabular}{|c|c|c|c|c|}
\hline \multirow[b]{2}{*}{ Variable } & \multicolumn{2}{|c|}{ Rainfall } & \multicolumn{2}{|c|}{ Throughfall } \\
\hline & PC 1-R & PC 2-R & PC 1-TR & PC 2-TR \\
\hline $\mathrm{Na}^{+}$ & -0.24 & 0.82 & -0.93 & -0.13 \\
\hline $\mathrm{K}^{+}$ & -0.82 & -0.18 & -0.92 & -0.32 \\
\hline $\mathrm{Mg}^{2+}$ & -0.89 & -0.10 & -0.84 & -0.17 \\
\hline $\mathrm{Ca}^{2+}$ & -0.36 & -0.44 & -0.82 & -0.01 \\
\hline $\mathrm{NH}_{4}^{+}$ & -0.65 & -0.40 & -0.51 & 0.31 \\
\hline $\mathrm{Cl}^{-}$ & -0.68 & 0.49 & -0.90 & -0.36 \\
\hline $\mathrm{NO}_{3}^{-}$ & -0.57 & 0.42 & -0.29 & -0.44 \\
\hline $\mathrm{SO}_{4}^{2-}$ & -0.87 & 0.11 & -0.88 & -0.28 \\
\hline Al III & $\longrightarrow$ & $\longrightarrow$ & -0.53 & 0.39 \\
\hline $\mathrm{Fe}$ III & -0.60 & -0.71 & -0.45 & 0.40 \\
\hline $\mathrm{Cu}$ II & -0.18 & -0.67 & -0.39 & 0.20 \\
\hline Zn II & -0.40 & 0.49 & -0.37 & 0.79 \\
\hline Mn II & -0.60 & 0.24 & -0.45 & 0.76 \\
\hline $\begin{array}{l}\text { Observed } \\
\text { eigenvalue }\end{array}$ & 4.53 & 3.10 & 6.19 & 3.25 \\
\hline $\begin{array}{c}\text { Broken-Stick } \\
\text { eigenvalue }\end{array}$ & 2.75 & 2.10 & 2.25 & 2.20 \\
\hline$\%$ of variance & 37.77 & 22.90 & 44.19 & 15.81 \\
\hline
\end{tabular}


(a)

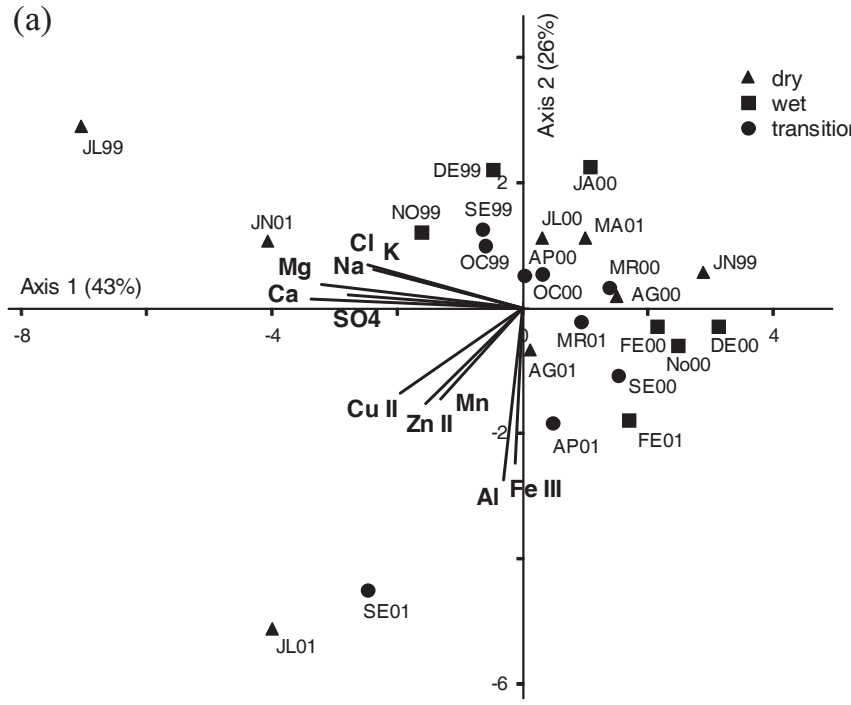

(b)

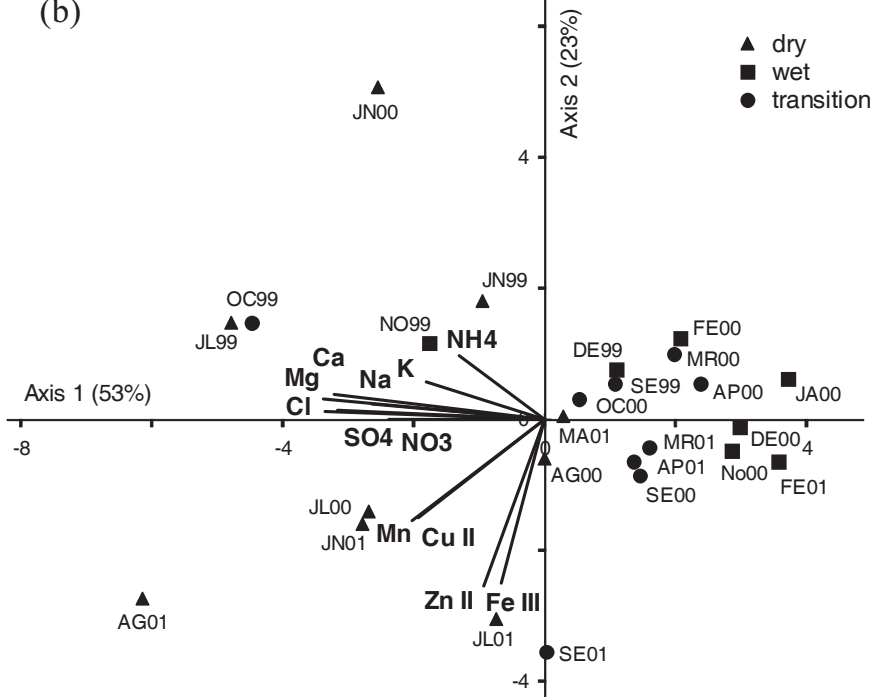

Fig. 7. PCA biplot of variables and scores for the rainfall (a) and throughfall (b) water samples at PEFI. The samples are labelled with month and year, with the symbols representing the climatic periods. For variables correlation with principal components see Table 3.

(a)

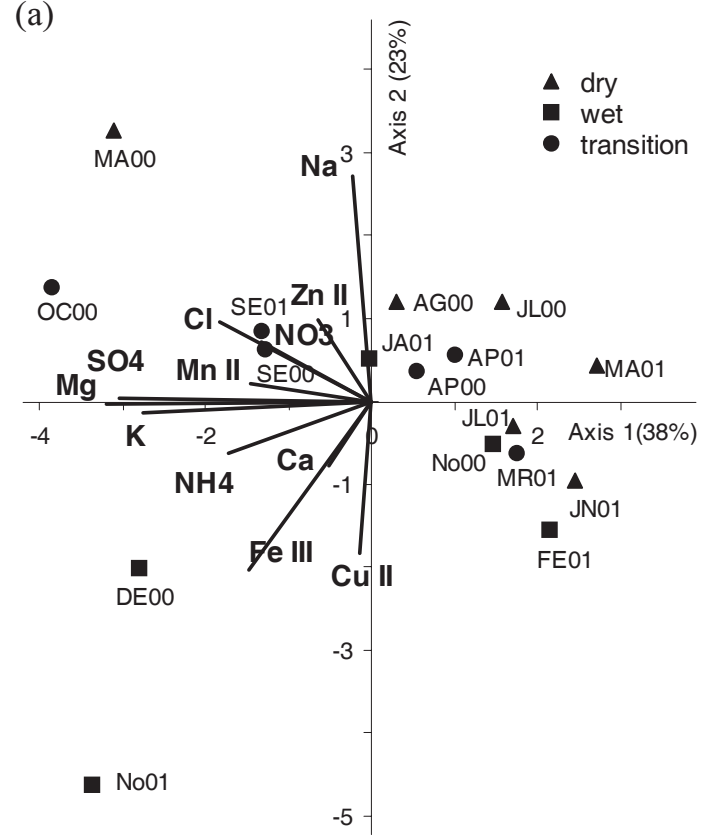

(b)

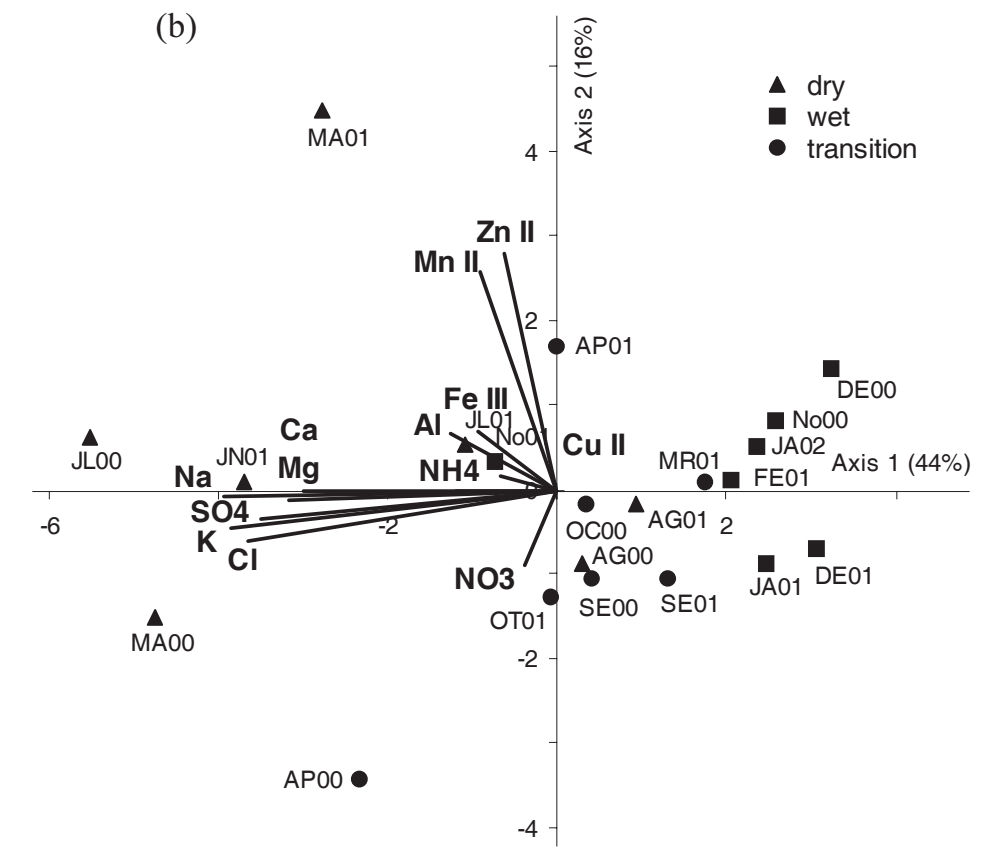

Fig. 8. PCA biplot of variables and scores for the rainfall (a) and throughfall (b) water samples at CUNHA. The samples are labelled with month and year, with the symbols representing the climatic periods. For correlation of variables with principal components see Table 4.

\section{DEPOSITION OF CHEMICAL SPECIES FROM RAINFALL AND TRHOUGHFALL}

The volume weighted mean values of the total amount of each species deposited in $\mathrm{kg} \mathrm{ha}^{-1} \mathrm{yr}^{-1}$ were determined by multiplying the concentration by the annual rainfall amount while seasonal deposition was calculated for the four wettest and driest months. (Table 5).

As regards annual depositions, there are marked anthropogenic inputs of $\mathrm{Ca}^{2+}, \mathrm{NO}_{3}{ }^{-}$and $\mathrm{SO}_{4}{ }^{2-}$ and transition metals at PEFI as compared to CUNHA, but Al III comes from soil dust sources at CUNHA. The estimated depositions for the transition metals are a fraction of the actual ones because in this work only their cation form is considered. The $\mathrm{NH}_{4}^{+}$fluxes are equivalent in the two areas during the rainy period; however, equivalent depositions do not mean equivalent sources. During the wettest period larger 
Table 5. Annual $\left(\mathrm{kg} \cdot \mathrm{ha}^{-1} \cdot \mathrm{yr}^{-1}\right)$ and seasonal deposition $\left(\mathrm{kg} \cdot \mathrm{ha}^{-1}\right.$ : four wettest and driest months) through the rainwater $(\mathrm{CH})$ and throughfall (TR) for PEFI and CUNHA areas.

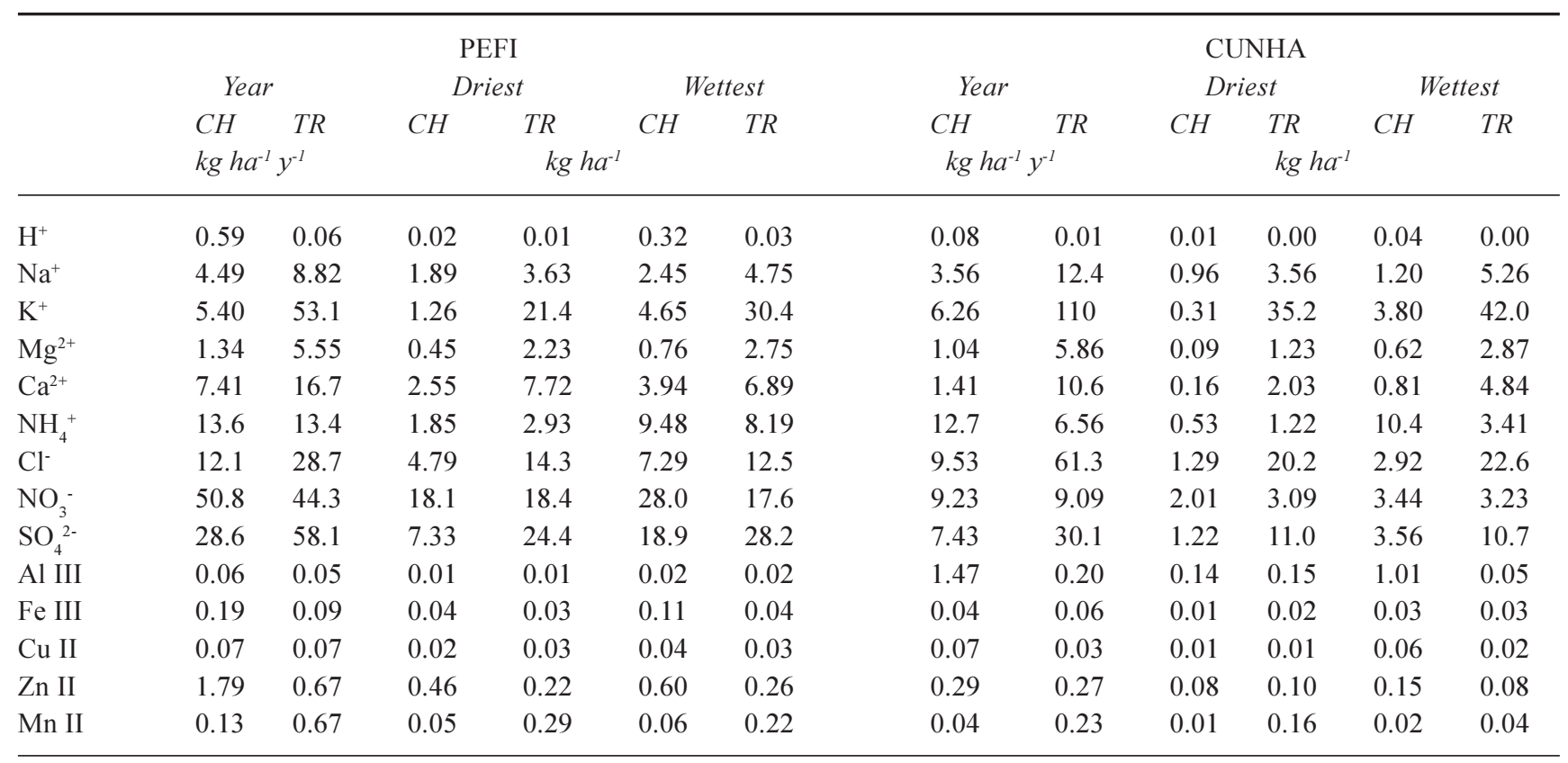

quantities of all species are deposited than in the driest one because during the wettest months, higher rainfall results in higher depositions at both sites. These results are higher than those from other Brazilian cities (Forti et al., 2001) (Table 6). Depositions at CUNHA are similar to those in a town in the same region on the sea border (Caraguatatuba); values are higher that those found in the Amazon forest for nitrate and sulphate. However, the amount of nitrate at PEFI is by far the largest of all cities.

Throughfall net depositions differ in the two areas, reflecting not only the polluted atmosphere at PEFI and the relatively clean one at CUNHA but also differences in the vegetation and in the nutritional status of that vegetation; these values are shown in Table $7 . \mathrm{NH}_{4}{ }^{+}$and $\mathrm{NO}_{3}^{-}$are both absorbed in a dry period but less $\mathrm{NO}_{3}^{-}$is absorbed in the wet one, when $\mathrm{NH}_{4}^{+}$is removed from the vegetation.

The deposition rates for $\mathrm{Na}^{+}, \mathrm{K}^{+}, \mathrm{Mg}^{2+}$ and $\mathrm{Ca}^{2+}$ at CUNHA are similar for the two periods studied. $\mathrm{NH}_{4}{ }^{+}$is absorbed in both, in larger amounts in the wettest period and $\mathrm{NO}_{3}^{-}$is absorbed in the driest period. In the wettest period, $\mathrm{NO}_{3}{ }^{-}$is deposited mainly in rainfall. More $\mathrm{Cl}^{-}$and $\mathrm{SO}_{4}{ }^{2-}$ are deposited in the dry period, mainly in throughfall: the main source of these species is the sea and they are deposited as gas or particles on the vegetation from which they are subsequently washed by the rain.

The concentrations for the transition metals may be underestimated because they refer only to their free metallic ions form rather than to the total amount and transition
Table 6. Nitrate and sulphate deposition values (in $\mathrm{kg} \mathrm{ha}^{-1} \mathrm{yr}^{-1)}$ for other Brazilian regions

\begin{tabular}{|c|c|c|}
\hline Areas near sea shore & $\mathrm{NO}_{3}^{-}$ & $\mathrm{SO}_{4}{ }^{2-}$ \\
\hline \multicolumn{3}{|c|}{ Highly-Moderately industrialised (more then a million inhabitants) } \\
\hline Porto Alegre & 6.82 & 178 \\
\hline Florianópolis & 4.96 & 268 \\
\hline Cubatão/Mogi & 48.4 & 310 \\
\hline Fortaleza & 4.96 & 13.5 \\
\hline Niteroi/RJ & 8.06 & 22.6 \\
\hline \multicolumn{3}{|c|}{ Urban (less then 500 million inhabitants) } \\
\hline Caraguatatuba & 8.06 & 21.1 \\
\hline Natal & 0.62 & 3.36 \\
\hline \multicolumn{3}{|l|}{$\underline{\text { Rural }}$} \\
\hline Cubatão/Paranapiacaba & 5.58 & 44.2 \\
\hline Piracicaba* & 9.92 & 12.0 \\
\hline \multicolumn{3}{|l|}{ Amazon Forest } \\
\hline Central** & 4.96 & 20.1 \\
\hline Northeastern & 4.34 & 14.9 \\
\hline $\begin{array}{l}\text { Source: Forti et al. } 2001 \\
* \text { more them } 150 \mathrm{~km} \text { from sea } \\
* * \text { about } 1000 \mathrm{~km} \text { from sea }\end{array}$ & & \\
\hline
\end{tabular}


Table 7. Net throughfall deposition $\left(\mathrm{kg} \cdot \mathrm{ha}^{-1} \cdot \mathrm{yr}^{-1}\right)$ for the whole period and the driest and wettest ones $\left(\mathrm{kg} \cdot \mathrm{ha}^{-1}\right)$.

\begin{tabular}{|c|c|c|c|c|c|c|}
\hline & & EFI & & & CUNH & \\
\hline & Total & Driest & Wettest & Total $I$ & Driest & Wettest \\
\hline $\mathrm{H}^{+}$ & -0.53 & -0.01 & -0.29 & -0.07 & -0.01 & -0.04 \\
\hline $\mathrm{Na}^{+}$ & 4.33 & 1.74 & 2.30 & 8.84 & 2.60 & 4.06 \\
\hline $\mathrm{K}^{+}$ & 47.7 & 20.1 & 25.8 & 104 & 34.9 & 38.2 \\
\hline $\mathrm{Mg}^{2+}$ & 4.21 & 1.78 & 1.99 & 4.82 & 1.14 & 2.25 \\
\hline $\mathrm{Ca}^{2+}$ & 9.29 & 5.17 & 2.95 & 9.19 & 1.87 & 4.03 \\
\hline $\mathrm{NH}_{4}^{+}$ & -0.20 & 1.08 & -1.29 & -6.14 & 0.69 & -6.99 \\
\hline $\mathrm{Cl}^{-}{ }^{4}$ & 16.6 & 9.51 & 5.21 & 51.8 & 18.9 & 19.7 \\
\hline $\mathrm{NO}_{3}^{-}$ & -6.50 & 0.30 & -10.4 & -0.14 & 1.08 & -0.21 \\
\hline $\mathrm{SO}_{4}^{2-}$ & 29.5 & 17.1 & 9.30 & 22.7 & 9.78 & 7.14 \\
\hline $\mathrm{Al}$ III & -0.01 & 0.00 & 0.00 & -1.27 & 0.01 & -0.96 \\
\hline Fe III & -0.10 & -0.01 & -0.07 & 0.02 & 0.01 & 0.00 \\
\hline $\mathrm{Cu}$ II & 0.00 & 0.01 & -0.01 & -0.04 & 0.00 & -0.04 \\
\hline Zn II & -1.12 & -0.24 & -0.34 & -0.02 & 0.02 & -0.07 \\
\hline Mn II & 0.54 & 0.24 & 0.16 & 0.19 & 0.15 & 0.02 \\
\hline
\end{tabular}

metals in colloidal and complexed form can be important. Therefore, their estimated deposition rates may well represent only a fraction of the real input to the areas. The natural source of Al III is the soil, though in PEFI, the Al III anthropogenic contribution is important and Al III may be solubilised from the dust deposited over the canopy. As a function of changes in the $\mathrm{pH}$ of the solution, deposition values may indicate that precipitation of Al III may be occurring. The same is probably true for Fe III, while Zn II and $\mathrm{Mn}$ II are important micronutrients and therefore active species within the canopy. The deposition values indicate that the vegetation is absorbing $\mathrm{Zn} \mathrm{II}$ and that $\mathrm{Mn}$ II is being leached from the vegetation. $\mathrm{Cu}$ II is found in trace amounts. Studies of the chemical composition of urban particulate matter showed that trace metals such as $\mathrm{Cu}, \mathrm{Mn}$ and $\mathrm{Zn}$ are present in readily water-soluble and available forms (Fernandéz-Espinosa et al., 2002; Voutsa and Samara, 2002). Kyotani and Iwatsuki (2002) pointed out that most of these elements are present as sulphates, nitrates and chlorides; this explains why they are leached easily from vegetation by rain and throughfall after dry deposition and/or rain events. Knowledge of these transition metals in rainfall and throughfall is rare and detailed studies are necessary to understand their functioning in these solutions.

The removal of active elements in the biogeochemical cycles as $\mathrm{K}, \mathrm{Mn}$ and $\mathrm{N}$ reflects leaching or consumption processes by the foliar surfaces. $\mathrm{K}^{+}$is easily leached from the vegetation and its flux at CUNHA is twice that calculated for PEFI. Arcova and Cicco (1987) also observed high K fluxes in this region. In other tropical forest regions such as the preserved forests of Panama (Golley et al., 1978), in São Paulo State, (Meguro et al., 1979), and in the Cardoso Island Atlantic forest (Varjabedian, 1994), amongst others, high potassium fluxes in throughfall have been found. According to Lopes (2000), the high humidity environment of these tropical forests favours $\mathrm{K}$ internal recycling as well as its leaching from the arboreal vegetation and its associated epiphytic flora. The lower fluxes of $\mathrm{K}^{+}$observed at PEFI can be attributed to a deficiency of that nutrient in the vegetation, which can be related to a lack of $\mathrm{K}^{+}$in the soil. Fluxes of $\mathrm{Mg}^{2+}$ in PEFI are larger than in CUNHA, reflecting a larger availability in the vegetation; its leaching from the vegetation has been associated with low concentrations in the soil solution and in the drainage waters so that $\mathrm{Mg}$ is recycled quickly by the vegetation (Nihlgärd et al., 1994).

$\mathrm{Mg}^{2+}$ is an important nutrient and is usually leached from the vegetation together with $\mathrm{K}^{+}$. Although an anthropogenic source of Mg certainly exists at PEFI, its flux is the same as that at CUNHA, suggesting that the vegetation at PEFI is also deficient in $\mathrm{Mg}$. The smaller fluxes of $\mathrm{K}^{+}$and $\mathrm{Mg}^{2+}$ at PEFI may well be a consequence of the high deposition rates of anions that take with them the basic cations. One of the effects related strongly with soil acidification is the leaching of nutrients such as potassium, calcium, magnesium and ammonium (Lopes, 2000).

In CUNHA, deposition rates are low. $\mathrm{NH}_{4}^{+}$absorption occurred mainly during the rainy period, at which season the transfer of $\mathrm{NO}_{3}^{-}$to throughfall was low. In PEFI, deposition rates are high with no substantial transference of both ions to throughfall. $\mathrm{NH}_{4}^{+}$is absorbed in the dry season and transferred at low rates during the rainy season, whereas $\mathrm{NO}_{3}{ }^{-}$is absorbed at high rates over the whole year. Annual figures of $1.5 \%$ and $12 \%$ of $\mathrm{NO}_{3}{ }^{-}$absorption were registered for CUNHA and PEFI, respectively.

Such differences in deposition, absorption, and transference of $\mathrm{NH}_{4}{ }^{+}$and $\mathrm{NO}_{3}{ }^{-}$probably reflect the composition and functioning of the natural plant communities in the contrasting areas. In the heavily polluted industrial area of Cubatão (SP, Brazil), $\mathrm{NH}_{3} / \mathrm{NH}_{4}^{+}$was the predominant form of nitrogen in wet deposition, as well as a probable nitrogen source for vegetation; the study by Steward et al., (2002) of nitrogen isotope signatures of vegetation in the area indicated the presence of species that used deposited $\mathrm{NH}_{3} / \mathrm{NH}_{4}^{+}$as their main source of nitrogen, as well as species with a high potential for using $\mathrm{NO}_{2}$ or $\mathrm{NO}_{3}{ }^{-}$as nitrogen sources. Moreover, the vegetative succession must be taken into account as PEFI is a disturbed area. Recent results for an Atlantic Forest succession in southeastern Brazil (Aidar et al., 2003) indicated a continuum of species with different nitrogen use strategies 
across the forest. Representing the extremes, the pioneer species had high leaf nitrogen contents and a high capacity for leaf nitrate assimilation, and responded to the increase in soil nitrogen availability, whereas late secondary species had low leaf nitrogen contents, low leaf nitrate assimilation capacity and little capacity to respond to soil nitrogen availability among other characteristics. Therefore, nitrogen transference through the canopy is closely linked to the nitrogen use strategies of different species and may be indicative of anthropogenic sources of nitrogen as well as of the vegetation structure and functioning. PEFI vegetation is a mosaic, with degraded and recovering areas having different successional species and just a few dominant ones (Pivello and Peccinini, 2002). Consequently, the area is expected to have a high capacity for nitrogen use.

$\mathrm{Ca}^{2+}$ is more vulnerable to the leaching processes during senescence as it is mostly present in the structural parts of the vegetation. However, such periods were not identified in this work. Some of the $\mathrm{Ca}^{2+}$ fluxes at PEFI certainly originated in building construction and in dust resuspended by vehicular traffic.

The presence in the throughfall solution of less active elements in the biogeochemical cycle, such as $\mathrm{Cl}$ and $\mathrm{S}$, for which the leaching and consumption are irrelevant, originated from direct deposition over the canopy. These chemicals have a natural source in marine aerosols and in the condensation nuclei in clouds and are incorporated by the throughfall through the washout of the vegetation. At CUNHA, one important source of $\mathrm{SO}_{4}^{2-}$ is the marine aerosol, while at PEFI anthropogenic sources are dominant over the natural ones.

Fluxes of transition metals are generally low even at PEFI and this is certainly because they have been underestimated here. Significant fluxes were found for Zn II and for Mn II, essential metals (micronutrients) for the vegetation; retention of $\mathrm{Zn}$ II by the vegetation indicates that it is being fixed. For Mn II, removal rates from the vegetation at PEFI are $80 \%$ while at CUNHA they range from $82 \%$ on average to $94 \%$ during the wettest period.

\section{Conclusions}

The characteristics of deposition of the major species and transition metals in contrasting Atlantic Forest areas differ. In an area of remnant forest in an urban environment with high atmospheric pollution, the deposition of solutes from rain is much higher than that far from major urban centres. The analysis of net throughfall fluxes provides evidence for differences in the nutritional status of the vegetation in the two areas. These differences can be attributed to the action of pollutants on the mass of vegetation as well as on the soils which are affected by high inputs of nitrate and sulphate that lower values of $\mathrm{pH}$, so inducing acid substances in the soil. In addition to the direct effect on the canopy, the local vegetation will become degraded because of a decrease in the nutrient supply and/or a nutritional disequilibrium As reported by Lopes (2000) for the Atlantic Forest in the Cubatão area, the degradation of vegetation results in a loss of nutrients because, together with the soil organisms, they are important in nutrient storage and recycling and in maintaining the closed internal cycles and preventing losses by leaching.

\section{Acknowledgements}

This work has been supported by the State of São Paulo Research Foundation (FAPESP) Process FAPESP 99/052044. The authors thank technicians Veralucia C. de Lima (IAG/ USP) and João B. A. dos Santos (IF/SMA) whose field activities made this work possible, as well as the anonymous reviewers for suggesting revisions to this paper.

\section{References}

Aidar, M.P.M., Schmidt, S., Moss, G., Stewart, G.R. and Joly, C.A., 2003. Nitrogen use strategies of neotropical rainforest trees in threatened Atlantic Forest. Plant Cell Environ., 26, 389-399.

Almeida, F.F.M., 1974. Fundamentos geológicos do relevo paulista. Serie: Teses-Monografias do Inst. Geogr. Univ. S Paulo, São Paulo, 14, 5-99.

Arcova, F.C.S. and de Cicco, V., 1987. Fluxo de nutrientes através da precipitação, precipitação interna e escoamento pelo tronco em floresta natural secundária no Parque Estadual da Serra do Mar - Núcleo Cunha - SP. Boletim Técnico do I.F., São Paulo, 41, 37-58.

Arcova, F.C.S., de Cicco, V. and Shimomichi, P.Y., 1993. Qualidade da água e dinâmica dos nutrientes em bacia hidrográfica recoberta por floresta de Mata Atlântica. Rev. Inst. Flor. São Paulo, 5, 1-21.

Bicudo, D.C., Forti, M.C. and Bicudo, C.E., 2002. Parque Estadual das Fontes do Ipiranga (PEFI) - Unidade de Conservação Ameaçada pela Urbanização de São Paulo, Edited by State Secretary of the Environment (Secretaria estadual do Meio Ambiente), 351pp.

Fernandes, A.J., Reis, L.A.M. and Carvalho, A., 2002. Caracterização do Meio Físico. In: Parque Estadual das Fontes do Ipiranga (PEFI): uma unidade de conservação ameaçada pela urbanização de São Paulo, D.C. Bicudo, M.C. Forti and C.E.M.Bicudo (Eds.) Secretaria do Meio Ambiente do Estado de São Paulo, Brazil. 49-62.

Fernandéz-Espinosa, A.J., Rodriguéz, M.T., Rosa, J.B. and Sánchez, J.C.J., 2002. A chemical speciation of trace metals for fine urban particles. Atmos. Environ., 36, 773-780.

Forti, M.C., Melfi, A.J., and Amorim, P.R.N., 1997. Hidroquímica das águas de drenagem de uma pequena bacia hidrográfica no nordeste da Amazônia: efeitos de sazonalidade (Estado do Amapá, BR). Geochim. Bras., 11, 325.

Forti, M.C., Boulet, R., Melfi, A.J. and Neal, C., 2000a. Hydrochemistry of a small catchment in Northeastern Amazonia: a comparison between natural with deforested parts of the 
catchment (Serra do Navio, Amapá State, Brazil). Water Air Soil Pollut., 118, 263-279.

Forti, M.C., Melfi, A.J., Astolfo, R. and Fostier, A.-H., 2000 b. Rainfall chemistry composition in two ecosystems in the northeastern Brazilian Amazon (Amapá State). J. Geophys. Res., 105D, 28895-28905.

Forti, M.C., Carvalho, A., Melfi, A.J. and Montes, C.R., 2001. Deposition patterns of $\mathrm{SO}_{4}^{2-}, \mathrm{NO}_{3}^{-}$and $\mathrm{H}^{+}$in the Brazilian Territory. Water Air Soil Pollut., 130, 1121-1126.

Golley, F.B., McGinnis, J.T., Clements, R.G. Child, G.I. and Duever, M.J., 1978. Ciclagem de minerais em um ecossistema de floresta tropical úmida. Editora da Universidade de São Paulo (EDUSP), São Paulo, Brazil. 265pp.

Jackson, D.A., 1993. Stopping rules in principal components analysis: a comparison of heuristical and statistical approaches. Ecology, 74, 2204-2214.

Johnson, R.A. and Wichern, D.W., 1988. Applied multivariate statistical analysis. Prentice-Hall, Englewood Cliffs, New Jersey, USA.

Kyotani, T. and Iwatsuki, M., 2002. Characterization of soluble and insoluble components in $\mathrm{PM}_{25}$ and $\mathrm{PM}_{10}$ fractions of airborne particulate matter in Kofu city, Japan. Atmos. Environ., 36, 639-649.

Lopes, M.I.M.S., 2000. Fluxo de água, balanço químico e alterações no solo Floresta Atlântica atingida pela poluição aérea de Cubatão, SP, Brasil. PhD. Thesis, University of São Paulo State, Brazil. 188 pp.

Meguro, M., Vinueza, G.N. and Delitti, W.B.C., 1979. Ciclagem de nutrientes na mata mesófila secundária - São Paulo. II: o papel da precipitação na importação de potássio e fósforo. Boletim de Botânica, Universidade de São Paulo, Brazil. 7, 61-67.
McCune, B. and Mefford, M.J., 1999. PC-ORD for Windows. Multivariate analysis of ecological data, version 4.10. MjM Software Design, Oregon, USA. 47 pp.

Nihlgärd, B.J., Swank, W.T. and Mitchell, M.J., 1994. Biological processes and catchment studies in: Biogeochemistry of small catchment. A tool for research, B.Moldan and J.Cerny (Eds.). SCOPE 51, Wiley, Chichester, UK. 133-161,

Pivello, V.R. and Peccinini, A.A., 2002. A vegetação do PEFI, In: Parque Estadual das Fontes do Ipiranga (PEFI): uma unidade de conservação ameaçada pela urbanização de São Paulo, D.C. Bicudo, M.C. Forti and C.E.M.Bicudo (Eds.). Secretaria do Meio Ambiente do Estado de São Paulo, Brazil. 75-93.

Robson, A.J. and Neal, C., 1997. Regional water quality of river Tweed. Sci. Total Environ., 194/194, 173-192.

Santos, M.P. and Funari, F.L., 2002. Clima Local, In: Parque Estadual das Fontes do Ipiranga (PEFI): uma unidade de conservação ameaçada pela urbanização de São Paulo, D.C.Bicudo, M.C.Forti and C.E.M.Bicudo, (Eds.) Secretaria do Meio Ambiente do Estado de São Paulo, Brazil. 29-48.

Shepherd, G.J. 1996. Fitopac 1: manual do usuário. Departamento de Botânica, UNICAMP. Campinas, Brazil. 95pp.

Steward, G.R., Aidar, M.P.M., Joly, C.A. and Schmidt, S., 2002. Impact of point source pollution on nitrogen isotope signatures $\left({ }^{15} \mathrm{~N}\right)$ of vegetation in SE Brazil. Oecologia, 131, 468-472.

Varjabedian, R., 1994. Aspectos comparativos da ciclagem de nutrientes minerais em Mata Atlântica de encosta e em mata sobre restinga, no Parque Estadual da Ilha do Cardoso, SP. Master Thesis, University of São Paulo State, Brazil. 177pp.

Voutsa, D. and Samara, C., 2002. Labile and bioaccessible fractions of heavy metals in the airborne particulate matter from urban and industrial areas. Atmos. Environ., 36, 3583-3590. 